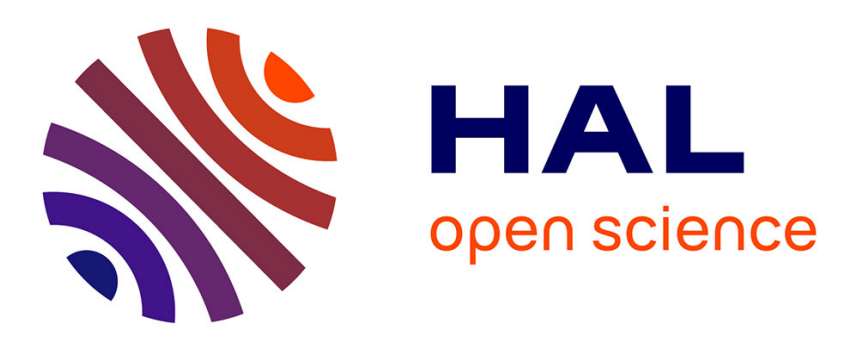

\title{
Optimization of struvite precipitation in synthetic biologically treated swine wastewater - Determination of the optimal process parameters
}

Aurélie Capdevielle, Eva Sýkorová, Béatrice Biscans, Fabrice Béline, Marie-Line Daumer

\section{To cite this version:}

Aurélie Capdevielle, Eva Sýkorová, Béatrice Biscans, Fabrice Béline, Marie-Line Daumer. Optimization of struvite precipitation in synthetic biologically treated swine wastewater - Determination of the optimal process parameters. Journal of Hazardous Materials, 2013, 244-245, pp.357-369. 10.1016/j.jhazmat.2012.11.054 . hal-00875743

\section{HAL Id: hal-00875743 \\ https://hal.science/hal-00875743}

Submitted on 22 Oct 2013

HAL is a multi-disciplinary open access archive for the deposit and dissemination of scientific research documents, whether they are published or not. The documents may come from teaching and research institutions in France or abroad, or from public or private research centers.
L'archive ouverte pluridisciplinaire HAL, est destinée au dépôt et à la diffusion de documents scientifiques de niveau recherche, publiés ou non, émanant des établissements d'enseignement et de recherche français ou étrangers, des laboratoires publics ou privés. 


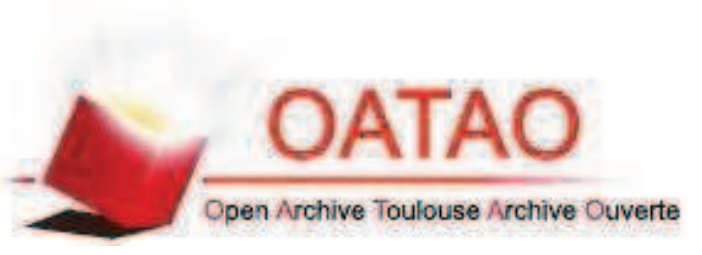

\section{Open Archive TOULOUSE Archive Ouverte (OATAO)}

OATAO is an open access repository that collects the work of Toulouse researchers and makes it freely available over the web where possible.

This is an author-deposited version published in : http://oatao.univ-toulouse.fr/ Eprints ID : 9736

To link to this article : DOI:10.1016/j.jhazmat.2012.11.054

URL : http://dx.doi.org/10.1016/j.jhazmat.2012.11.054

To cite this version :

Capdevielle, Aurélie and Sýkorová, Eva and Biscans, Béatrice and Béline, Fabrice and Daumer, Marie-Line Optimization of struvite precipitation in synthetic biologically treated swine wastewater Determination of the optimal process parameters. (2013) Journal of Hazardous Materials, vol. 244-245 . pp. 357-369. ISSN 0304-3894 


\title{
Optimization of struvite precipitation in synthetic biologically treated swine wastewater-Determination of the optimal process parameters
}

\author{
Aurélie Capdevielle ${ }^{\mathrm{a}, \mathrm{d}, *}$, Eva Sýkorová ${ }^{\mathrm{b}}$, Béatrice Biscans ${ }^{\mathrm{c}}$, Fabrice Béline $^{\mathrm{a}}$, Marie-Line Daumer ${ }^{\mathrm{a}}$ \\ a IRSTEA/Cemagref, 17 avenue de Cucillé, CS 64427, 35044 Rennes Cedex, France \\ b ICT Prague, Department Technology of water, Technická 5, Prague 6, 166 28, Czech Republic

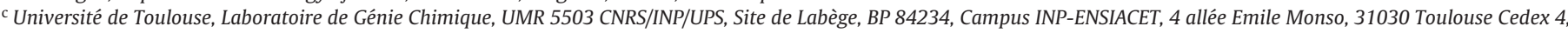 \\ France \\ d Université européenne de Bretagne (UEB), 5 Boulevard Laënnec, 35000 Rennes, France
}

\section{H I G H L I G H T S}

Struvite precipitation is mainly influenced by the quantity of MgO added.

Optimized parameters favoured struvite formation despite of high $\left[\mathrm{Ca}^{2+}\right]$ without adding other reagents.

$90 \%$ of the total dissolved phosphorus is recovered as large crystals of struvite.

Raman spectroscopy and solid dissolution show co-precipitation of ACP and presence of $\mathrm{CaCO}_{3}$ in solid.

\begin{abstract}
A B S T R A C T
A sustainable way to recover phosphorus $(\mathrm{P})$ in swine wastewater involves a preliminary step of P dissolution followed by the separation of particulate organic matter. The next two steps are firstly the precipitation of struvite crystals done by adding a crystallization reagent (magnesia) and secondly the filtration of the crystals. A design of experiments with five process parameters was set up to optimize the size of the struvite crystals in a synthetic swine wastewater. More than $90 \%$ of P was recovered as large crystals of struvite in optimal conditions which were: low Mg:Ca ratio (2.25:1), the leading parameter, high N:P ratio (3:1), moderate stirring rate (between 45 and $90 \mathrm{rpm}$ ) and low temperature (below $20^{\circ} \mathrm{C}$ ).These results were obtained despite the presence of a large amount of calcium and using a cheap reactant (MgO). The composition of the precipitates was identified by Raman analysis and solid dissolution. Results showed that amorphous calcium phosphate (ACP) co-precipitated with struvite and that
\end{abstract}

Struvite

P-recovery

$\mathrm{MgO}$

Calcium phosphate

Swine wastewater

Raman

\section{Introduction}

The soil in Brittany (France) is extremely rich in phosphorus (P) because of intensive pig farming. P moves into surface waters due to soil erosion, and takes part in their eutrophication. Whilst needs of $\mathrm{P}$ as fertilizer increase every year, phosphate reserves are estimated to run out in 100 years [1]. P has to be recycled from our wastes. Therefore, some processes have been developed to recycle dissolved $\mathrm{P}$ as mineral fertilizer from urban wastewater. Calcium phosphate and struvite are the two forms of phosphate fertilizer produced. Struvite is known as a slow release fertilizer with

\footnotetext{
* Corresponding author at: IRSTEA/Cemagref, 17 avenue de Cucillé, CS 64427, 35044 Rennes Cedex, France.

E-mail addresses: aurelie.capdevielle@irstea.fr (A. Capdevielle), eva.sykorova@vscht.cz (E. Sýkorová), beatrice.biscans@ensiacet.fr (B. Biscans).
}

comparable performances to, or even higher than, superphosphate from ore [2]. However, struvite recovery process, that recycles a significant amount of $\mathrm{P}$, is seldom applied to concentrated effluents such as swine wastewaters. One of the limitations is the form that $\mathrm{P}$ actually presents in swine manure: $80 \%$ of $\mathrm{P}$ is in the particulate part [3].

A sustainable way to recover $\mathrm{P}$ in swine wastewater involves a preliminary step of $\mathrm{P}$ dissolution at $\mathrm{pH} 4.5$ followed by the separation of residual particulate organic matter. Less reactant is needed when buffer effect is decreased by previously treating the effluent for nitrogen removal. The next two steps are: the precipitation of struvite crystals $\left(\mathrm{MgNH}_{4} \mathrm{PO}_{4} \cdot 6 \mathrm{H}_{2} \mathrm{O}\right)$ by adding a crystallization reagent (magnesia, $\mathrm{MgO}$ ) and the filtration of struvite crystals in filter bags with a $100 \mu \mathrm{m}$ cut-off [4].

$\mathrm{MgO}$ was chosen as the precipitation reagent as its cost is low, it is a by-product from the animal food industry, it is safe and it fits to agricultural restrictions. It has two main functions: to increase 
the $\mathrm{pH}$ value (6.5-11) and to get a molar ratio of $\mathrm{Mg}: \mathrm{N}: \mathrm{P}$ equal to $1: 1: 1$ in order to reach the conditions to precipitate struvite in the solution $[5,6]$. Nevertheless, the control of the $\mathrm{pH}$ value and the molar ratio of $\mathrm{Mg}$ :Ca cannot be controlled independently of each other.

The control of the mechanisms of precipitation is the main issue to obtain: high value-added products, predictable mineral composition and big struvite crystals.

The amount and size of crystals depend on nucleation rate and crystal growth. These two mechanisms have already been modelled $[7,8]$. Nucleation rate is described by (1).

$\mathrm{J}_{1, \text { hé } \mathrm{t}}\left[\mathrm{nb} \mathrm{m}^{-3} \mathrm{~s}^{-1}\right]=\mathrm{A}_{1 \text {, hé t }} \exp \left(-\mathrm{f} . \Phi_{\mathrm{v}} \frac{\mathrm{V}_{\mathrm{m}}^{2} \gamma_{\mathrm{g}, \mathrm{l}}^{3}}{(\mathrm{kT})^{3} \ln ^{2} \beta}\right)$

$\beta=\frac{\mathrm{a}_{\mathrm{Mg}^{2+}} \times \mathrm{a}_{\mathrm{NH}_{4}^{+}} \times \mathrm{a}_{\mathrm{PO}_{4}^{3-}}}{\mathrm{K}_{\text {struvite }}}$

$\mathrm{SI}=\log (\beta)$

$A_{1, \text { het }}$ is the nucleii agglomeration rate $\left(n b \cdot m^{-3} \cdot s^{-1}\right), V_{m}$ is the nucleii molar volume $\left(\mathrm{m}^{3}\right), \mathrm{k}$ the Boltzmann constant $=1.38 \times 10^{-23} \mathrm{~J} \cdot \mathrm{K}^{-1}, \quad \mathrm{~T}$ the temperature $(\mathrm{K}), \gamma_{\mathrm{g}, \mathrm{l}}$ the nuclei/liquid interfacial energy $\left(\mathrm{N} \cdot \mathrm{m}^{-1}\right), \quad \beta$ the supersaturation (2) and $\mathrm{f}$ and $\Phi_{\mathrm{v}}$ are shape factors. $\mathrm{a}_{\mathrm{i}}$ are the ion activities and $\mathrm{K}_{\text {struvite }}$ is the solubility product of the struvite. SI (3), the saturation index is used to predict the precipitation potential of struvite. $\beta$ is strongly dependant on the $\mathrm{pH}$ due to the dissolution of $\mathrm{MgO}$, to the $\mathrm{pK}_{\mathrm{a}}$ of the triprotic phosphoric acid (2.12, 7.21 and 12.67 at $25^{\circ} \mathrm{C}$ ) and the $\mathrm{pK}_{\mathrm{a}}$ of $\mathrm{NH}_{3} / \mathrm{NH}_{4}{ }^{+}$(9.25).

The growth rate of a crystal is described by a two step model: the transport of the solutes to the crystals and their integration into the crystal structure [7-10].

The diffusion-controlled $\left(G_{d}\right)$, the integration-controlled $\left(G_{r}\right)$ and the overall linear growth rate $\left(\mathrm{Gg}_{\mathrm{g}}\right)$ are described by the following equations (4), (5), (7) [7-9]. $G_{g}$ is the sum of $G_{d}$ and $G_{r}$ and can be expressed in function of the mass flux density (dm/dt) (7).

$\mathrm{G}_{\mathrm{d}}=\frac{\mathrm{L} \times \mathrm{A}}{3 \times \mathrm{V}_{\mathrm{p}} \times \rho_{\mathrm{c}}} \times \mathrm{k}_{\mathrm{d}} \times\left(\mathrm{c}-\mathrm{c}_{\mathrm{i}}\right)$

$\mathrm{G}_{\mathrm{r}}=\frac{\mathrm{L} \times \mathrm{A}}{3 \times \mathrm{V}_{\mathrm{p}} \times \rho_{\mathrm{c}}} \times \mathrm{k}_{\mathrm{r}} \times\left(\mathrm{c}_{\mathrm{i}}-\mathrm{c} *\right)^{\mathrm{r}}$

$\mathrm{k}_{\mathrm{r}}=\mathrm{k}_{\mathrm{r} 0} \times \exp \left(-\frac{\Delta \mathrm{E}_{\mathrm{r}}}{\mathrm{RT}}\right)$

$\mathrm{G}_{\mathrm{g}}=\frac{\mathrm{L} \times \mathrm{A}}{3 \times \mathrm{V}_{\mathrm{p}} \times \rho_{\mathrm{c}}} \times \mathrm{kg}_{\mathrm{g}} \times(\mathrm{c}-\mathrm{c} *)^{\mathrm{g}}=\frac{\mathrm{L}}{3 \times \mathrm{V}_{\mathrm{p}} \times \rho_{\mathrm{c}}} \times \frac{\mathrm{dm}}{\mathrm{dt}}$

Where $k_{d}(4)$ is the mass transfer coefficient, $k_{r}(6)$ is the reaction rate constant, $\mathrm{k}_{\mathrm{g}}$ is the growth rate constant, $\mathrm{r}$ is the order of the integration reaction, $\mathrm{k}_{\mathrm{r} 0}$ is the reaction constant, $\Delta \mathrm{E}_{\mathrm{r}}$ is the activation energy and $g(7)$ is the overall order of the growth process ( $g=1$ at high supersaturation and 2 at low supersaturation). $c, c_{i}$ and $c^{*}$ are the concentration of the solute, its concentration at the crystal-solution interface and its supersaturated concentration respectively. $c-c_{\mathrm{i}}$ is the driving force for diffusion and $c_{\mathrm{i}}-c^{*}$ is the driving force for reaction. $L$ is the average diameter of the crystal; $A$ is the area of the particle, $V_{p}$ its volume and $\rho_{c}$ the crystal density; $\mathrm{m}$ is the mass of the struvite formed.

In a continuous reactor, the struvite growth seems to follow a size dependent growth model [11]: the larger the crystals are, the faster the crystal grows. Nucleation and growth mechanisms are strongly dependent on $\mathrm{pH}$, supersaturation, temperature, ionic strength of solution, presence of foreign substances, design of crystallizer, stirring, residence time of crystals $[7,8]$. When the influent contains both calcium and magnesium, a pH range of 7 to 11 enables the precipitation of both struvite and calcium phosphate [12-16].
Table 1

Ionic concentrations of synthetic and real effluents.

\begin{tabular}{lll}
\hline Ionic concentrations $\left(\mathrm{mg} \mathrm{L}^{-1}\right)$ & Real effluent & Synthetic effluent \\
\hline $\mathrm{Na}^{+}$ & $524 \pm 163$ & $2083 \pm 152$ \\
$\mathrm{~K}^{+}$ & $1993 \pm 453$ & $1559 \pm 120$ \\
$\mathrm{Mg}^{2+}$ & $361 \pm 35$ & $345 \pm 19$ \\
$\mathrm{Ca}^{2+}$ & $694 \pm 108$ & $645 \pm 38$ \\
$\mathrm{Cl}^{-}$ & $1277 \pm 262$ & $2198 \pm 40$ \\
$\mathrm{NO}_{2}{ }^{-}-\mathrm{N}$ & $356 \pm 87$ & $293 \pm 3$ \\
$\mathrm{NO}_{3}{ }^{-}-\mathrm{N}$ & $68 \pm 10$ & $115 \pm 2$ \\
$\mathrm{PO}_{4}{ }^{3-}-\mathrm{P}$ & $654 \pm 232$ & $629 \pm 3$ \\
$\mathrm{SO}_{4}{ }^{2-}-\mathrm{S}$ & $113 \pm 31$ & $111 \pm 1$ \\
\hline
\end{tabular}

Competition between the two products will depend on several factors amongst which the Mg:Ca and N:P molar ratios [17-19].

Most of the studies [20-22] on struvite and calcium phosphate crystallization have been performed on pure synthetic medium containing only the ions directly involved in their composition. Real influents have also been studied but with lower ionic strength compared to the swine wastewater after $\mathrm{P}$ dissolution. In these studies, magnesium and $\mathrm{pH}$ increase were usually provided by soluble reactants $[21,23,24]$. Magnesia dissolution kinetic and ammonia volatilization were not taken into account while they do determine the Mg:Ca and N:P molar ratios.

This study focuses on the influence of the process parameters on the precipitation of struvite in complex medium like swine wastewater. Precipitation was carried out in synthetic medium with an ionic composition close to the acidified swine slurry entering the crystallization step of the process. The purpose was to improve the precipitation of struvite instead of calcium phosphate in a stirred batch reactor. The studied process parameters were stirring rate, temperature, $\mathrm{Mg}: \mathrm{Ca}$ and $\mathrm{N}: \mathrm{P}$ molar ratio. A design of experiments was set up to understand the influence of these variables over struvite precipitation and crystal size. The surface response was employed to optimize the quantity of large crystals of struvite.

\section{Experimental}

\subsection{Synthetic swine wastewater preparation}

$40 \mathrm{~L}$ of synthetic swine wastewater were prepared by mixing different salts in distilled water to obtain the ionic concentrations observed in the studied swine wastewater (Table 1). Formic acid (85\%, Carlos Erba) was added in the solution until pH reached 4.5.

The salts used for synthetic effluent preparation were: $\mathrm{KOH}$, $\mathrm{K}_{2} \mathrm{SO}_{4}, \mathrm{NaNO}_{2}, \mathrm{KNO}_{3}, \mathrm{CaCl}_{2} \cdot 2 \mathrm{H}_{2} \mathrm{O}$ (Carlo Erba), $\mathrm{MgCl}_{2} \cdot 6 \mathrm{H}_{2} \mathrm{O}$ and $\mathrm{Na}_{3} \mathrm{PO}_{4} \cdot 12 \mathrm{H}_{2} \mathrm{O}$ (Merck).

The ionic concentrations of synthetic swine wastewater were controlled by ion chromatography on Dionex DX-120. Concentrations for synthetic and real effluents are shown in Table 1.

The addition of a variable amount of $\mathrm{NH}_{4} \mathrm{Cl}$ powder (99\%, Carlo Erba) was performed $5 \mathrm{~min}$ before the beginning of each run to minimize the possible volatilization of $\mathrm{NH}_{3}$. The addition was performed under high stirring.

\subsection{Magnesia suspension}

Previous experiments (data not shown) showed that a suspension of $\mathrm{MgO}$ in water was much more effective than $\mathrm{MgO}$ powder directly introduced into the reactor. MgO suspension was better dispersed and its reactivity was improved. This kind of suspension was also used in a similar study by Münch et al. [25]. The MgO suspension was prepared by mixing $500 \mathrm{~g}$ of $\mathrm{MgO}$ powder $(97 \%$, VWR Prolabo) in $5 \mathrm{~L}$ of distilled water. Magnesia was kept in suspension under continuous stirring at $300 \mathrm{rpm}$ and was thermostated at the 
same temperature as the runs. The runs began when adding the suspension of $\mathrm{MgO}$.

\subsection{Equipment}

The runs were performed in a FC6s flocculator from Velp Scientifica. Six axial mixing blades are operated by six motors with various stirring rates from 10 to $200 \mathrm{rpm}$. Each beaker was filled with $800 \mathrm{~mL}$ of synthetic effluent. The addition of MgO was carried out under continuous stirring at $90 \mathrm{rpm}$ for $30 \mathrm{~s}$. Then, the stirring rate was maintained at the consigned value during $24 \mathrm{~h}$. The runs were carried out in vessels thermostated by water circulating through a constant temperature bath $\left(5^{\circ} \mathrm{C}, 20^{\circ} \mathrm{C}\right.$ or $\left.35^{\circ} \mathrm{C}\right)$. $\mathrm{pH}$ and temperature were recorded by a 8 channels data logger $\mathrm{PH} / \mathrm{MV} / \mathrm{ION} / \mathrm{O} 2$ from Fisher Scientific.

\subsection{Sampling}

Samples $(4 \mathrm{~mL})$ were collected from beakers every 30 min during $4 \mathrm{~h}$ and then after $24 \mathrm{~h}$ for dissolved compound analysis. At $4 \mathrm{~h}$ and $24 \mathrm{~h}$, a $250 \mathrm{~mL}$ sample was collected for particle analysis.

After $24 \mathrm{~h}$, samples were sieved on 25 and $100 \mu \mathrm{m}$ filters. The three solid fractions ( $<25 \mu \mathrm{m}, 25-100 \mu \mathrm{m}$ and $>100 \mu \mathrm{m}$ ) were dried at room temperature. Each fraction was then weighed and analyzed as described below.

\subsection{Analysis}

The composition of the collected fractions were analyzed by ion chromatography after solid dissolution by formic acid and by Raman spectroscopy. The precipitation rate was evaluated by monitoring the dissolved concentrations of $\mathrm{Ca}^{2+}, \mathrm{PO}_{4}{ }^{3-}, \mathrm{Mg}^{2+}$ and $\mathrm{NH}_{4}{ }^{+}$.

\subsubsection{Ionic concentration}

The concentrations of dissolved $\mathrm{PO}_{4}-\mathrm{P}, \mathrm{NH}_{4}-\mathrm{N}$ were analyzed by automate colorimetric methods on QuikChem ${ }^{\circledR}$ FIA+ from Lachat Instruments with QuikChem method 10-115-01-1-P and 10-10706-1-J respectively. The dissolved $\mathrm{Mg}^{2+}$ and $\mathrm{Ca}^{2+}$ were determined by cation chromatography.

The three solid fractions were acidified with formic acid (85\%, Carlo Erba) and diluted in $50 \mathrm{~mL}$ of distilled water. They were analyzed by cation and anion chromatography on Dionex DX-120 with an IonPac ${ }^{\mathrm{TM}} \mathrm{CS} 12 \mathrm{~A}$ column and an IonPac ${ }^{\mathrm{TM}}$ AS9-HC column respectively.

The molar balance was checked by analysing the solid and liquid composition at the beginning and the end of the run.

\subsubsection{Raman spectroscopy}

Analysis were carried out at room temperature using a Raman microscope (Kaiser Optical Systems, Leica DM1) equipped with a thermoelectrically cooled CCD detector coupled to the spectrometer with multi-mode fibre optic cables; $50 \mu \mathrm{m}$ diameter was employed for excitation, and $62.5 \mu \mathrm{m}$ diameter for collection. The excitation of Raman scattering was operated by a $400 \mathrm{~mW}$ diode laser operating at $785 \mathrm{~nm}$, with an average power output of 100-200 mW through an objective lens with a magnification of $20 \mathrm{X}$ and a working distance of $11 \mathrm{~mm}$. The spot size of the laser beam through the objective was approximately $20 \mu \mathrm{m}$. About $1 \mathrm{mg}$ of solid was introduced on a microscope slide. The microscope was focused visually, using a white light source to maximize the Raman signal. The collection range was $100-3100 \mathrm{~cm}^{-1}$. The time of collection was then adjusted at $2 \mathrm{~min}$ in order to obtain a good signal-to-noise ratio.

\subsection{Experimental design}

The response surface plan used is a Box-Behnken modified plan with 48 runs: 12 centre points and one repetition for the extremities. Five process parameters were studied: A, the stirring rate, $\mathrm{B}$, the temperature, $\mathrm{C}$, the $\mathrm{N}: \mathrm{P}$ molar ratio, $\mathrm{D}$, the initial $\mathrm{Mg}$ :Ca molar ratio and $\mathrm{E}$, the concentration of magnesium remaining as $\mathrm{MgO}$ particles.

$\mathrm{D}$ and $\mathrm{E}$ were originally grouped in one parameter: the $\mathrm{Mg}: \mathrm{Ca}$ molar ratio. However, the measurement of dissolved $\mathrm{Mg}^{2+}$ in the $\mathrm{MgO}$ suspension showed variations at the beginning of each block of runs. To better describe the results and understand the effects, $\mathrm{MgO}$ was considered as two parameters for statistical treatment of the experimental data: the initial dissolved $\mathrm{Mg}$ :Ca ratio and the remaining $\mathrm{Mg}^{2+}$ as $\mathrm{MgO},[\mathrm{Mg}-\mathrm{MgO}]$. These two parameters were calculated from the dissolved $\mathrm{Mg}^{2+}$ measures in $\mathrm{MgO}$ suspension. The correlation matrix of the experimental design showed that, even with this change, there was no risk of confusion.

The design matrix and experimental level of each variable are described in

Table 2. The studied responses were: ionic concentrations $\left(\mathrm{Ca}^{2+}\right.$, $\mathrm{PO}_{4}{ }^{3-}$ and $\mathrm{NH}_{4}{ }^{+}$) after $24 \mathrm{~h}$, the production of particles $>100 \mu \mathrm{m}$ and the proportion of struvite versus calcium phosphate in dried solids.

\subsection{Data evaluation}

The Box-Behnken modified plan uses a second order polynomial model (8) to predict the ionic concentration values as a function of a combination of the process parameters (stirring rate, initial dissolved Mg: Ca ratio, [Mg-MgO], N:P ratio and temperature) [26].

$Y=\beta_{0}+\sum_{i=1}^{5} \beta_{i} X_{i}+\sum_{i<j} \beta_{i j} X_{j}+\sum_{i=1}^{5} \beta_{i i} X_{i}^{2}+\varepsilon$

Where $\mathrm{Y}$ is the predictive response. In this paper, six responses were predicted and five were used for the optimization step. $\beta_{0}$ is the constant term. $\beta_{\mathrm{i}}$ are the coefficients of the linear parameters $X_{i}(A, B, C, D, E) . \beta_{i j}$ represents the coefficients of the interaction parameters $X_{i}$ and $X_{j}$ (for instance: $A B, A C, A D \ldots$ ). $\beta_{i i}$ represents the coefficients of the quadratic parameters $X_{i}^{2}$ (AA, BB, CC, DD and $\mathrm{EE}$ ) which show the quadratic dependence of the responses to a parameter.

Statgraphics Centurion XVI, 16.1.11 software was used for experimental design and data evaluation. The statistical models are said to fit the experimental data when the adjusted $R^{2}$ were greater than or equal to $65 \%$. A low probability F value ("Prob. > F") less than 0.05 indicates process parameters are significant.

\subsection{Determination of the final solid phases by PHREEQC®}

The saturation index (SI) of the various minerals was calculated using the geochemical software PHREEQC ${ }$ with the Minteq.V4 database. The database was modified to include the struvite and amorphous calcium phosphate (ACP) phases. The $\mathrm{K}_{\mathrm{sp}}$ values for struvite were adapted to the temperature of the runs according to Hanhoun et al. [27]. The $K_{s p}$ value for ACP was set at 26.83, the mean value of the $K_{\mathrm{sp}}$ for ACP from all the studies described by Mañas et al. [28]. The Ksp for brucite was set at 17.01 according to the study of Altmaier et al. [29].Several minerals were removed from the database as they cannot precipitate through the conditions of the runs: the monetite $\left(\mathrm{CaHPO}_{4}\right)$, the magnesite $\left(\mathrm{MgCO}_{3}\right)$, the aragonite $\left(\mathrm{CaCO}_{3}\right)$, the dolomite $\left(\mathrm{CaMg}\left(\mathrm{CO}_{3}\right)_{2}\right.$, the huntite $\left(\mathrm{Mg}_{3} \mathrm{Ca}\left(\mathrm{CO}_{3}\right)_{4}\right)$, the $\beta$-tricalciumphosphate $\left(\mathrm{Ca}_{3}\left(\mathrm{PO}_{4}\right)_{2}\right)$ as they can only form at high temperature $[30,31]$, the hydroxyapatite $\left(\mathrm{Ca}_{5}\left(\mathrm{PO}_{4}\right)_{3}(\mathrm{OH})\right)$ and the octocalciumphosphate (OCP, $\left.\mathrm{Ca}_{8}\left(\mathrm{HPO}_{4}\right)_{2}\left(\mathrm{PO}_{4}\right)_{4} \cdot 5 \mathrm{H}_{2} \mathrm{O}\right)$ as 
Table 2

The modified Box-Behnken design for optimization of 5 variables each at three levels.

\begin{tabular}{|c|c|c|c|c|c|}
\hline Runs & Stirring rate (rpm) & Initial Mg:Ca molar ratio & {$[\mathrm{Mg}-\mathrm{MgO}]\left(\mathrm{mg} \mathrm{L}^{-1}\right)$} & $\mathrm{N}: \mathrm{P}$ molar ratio & Temperature $\left({ }^{\circ} \mathrm{C}\right)$ \\
\hline Low & 10 & 0.63 & 475 & 0.71 & 5 \\
\hline Middle & 45 & 1.06 & 1228 & 2.03 & 20 \\
\hline High & 90 & 1.66 & 2617 & 3.11 & 35 \\
\hline 1 & 10 & 1.08 & 475 & 2.86 & 5 \\
\hline 2 & 45 & 1.10 & 475 & 1.96 & 5 \\
\hline 3 & 90 & 1.59 & 797 & 2.00 & 5 \\
\hline 4 & 10 & 1.66 & 797 & 1.00 & 5 \\
\hline 5 & 10 & 1.66 & 797 & 3.00 & 5 \\
\hline 6 & 45 & 1.57 & 797 & 2.00 & 5 \\
\hline 7 & 45 & 0.84 & 1607 & 2.00 & 5 \\
\hline 8 & 45 & 1.11 & 975 & 2.00 & 5 \\
\hline 9 & 45 & 1.14 & 1606 & 2.00 & 5 \\
\hline 10 & 45 & 1.09 & 975 & 3.00 & 5 \\
\hline 11 & 45 & 1.09 & 975 & 2.00 & 5 \\
\hline 12 & 90 & 0.71 & 975 & 3.00 & 5 \\
\hline 13 & 10 & 1.02 & 1657 & 2.00 & 20 \\
\hline 14 & 10 & 1.09 & 1026 & 3.00 & 20 \\
\hline 15 & 10 & 1.11 & 1026 & 2.13 & 20 \\
\hline 16 & 45 & 1.02 & 500 & 1.03 & 20 \\
\hline 17 & 45 & 0.99 & 1044 & 2.14 & 20 \\
\hline 18 & 45 & 1.00 & 1044 & 1.00 & 20 \\
\hline 19 & 45 & 1.13 & 991 & 1.89 & 20 \\
\hline 20 & 90 & 1.15 & 991 & 2.31 & 20 \\
\hline 21 & 45 & 0.91 & 1004 & 0.90 & 20 \\
\hline 22 & 45 & 1.02 & 1635 & 2.35 & 20 \\
\hline 23 & 45 & 1.08 & 1004 & 2.20 & 20 \\
\hline 24 & 45 & 1.07 & 478 & 2.15 & 20 \\
\hline 25 & 45 & 0.81 & 1052 & 2.14 & 20 \\
\hline 26 & 45 & 0.80 & 1683 & 2.10 & 20 \\
\hline 27 & 45 & 1.05 & 1052 & 1.93 & 20 \\
\hline 28 & 90 & 0.80 & 1052 & 1.95 & 20 \\
\hline 29 & 90 & 0.92 & 552 & 1.92 & 20 \\
\hline 30 & 45 & 0.95 & 1085 & 2.14 & 20 \\
\hline 31 & 45 & 0.63 & 552 & 2.14 & 20 \\
\hline 32 & 45 & 0.85 & 1085 & 2.89 & 20 \\
\hline 33 & 45 & 0.90 & 1087 & 2.25 & 20 \\
\hline 34 & 90 & 0.91 & 1718 & 2.14 & 20 \\
\hline 35 & 45 & 0.97 & 1087 & 2.13 & 20 \\
\hline 36 & 45 & 0.85 & 1087 & 1.19 & 20 \\
\hline 37 & 10 & 0.94 & 1637 & 2.48 & 35 \\
\hline 38 & 90 & 0.90 & 1637 & 0.71 & 35 \\
\hline 39 & 45 & 1.00 & 2608 & 2.86 & 35 \\
\hline 40 & 45 & 1.00 & 1160 & 1.96 & 35 \\
\hline 41 & 45 & 0.94 & 872 & 2.00 & 35 \\
\hline 42 & 45 & 0.96 & 1637 & 1.00 & 35 \\
\hline 43 & 90 & 1.18 & 1613 & 3.00 & 35 \\
\hline 44 & 10 & 1.18 & 1613 & 2.00 & 35 \\
\hline 45 & 45 & 1.43 & 2618 & 2.00 & 35 \\
\hline 46 & 45 & 1.30 & 2159 & 2.00 & 35 \\
\hline 47 & 45 & 1.35 & 2324 & 2.00 & 35 \\
\hline 48 & 45 & 1.18 & 2324 & 3.00 & 35 \\
\hline
\end{tabular}

according to the Ostwald's rules, the less stable forms (amorphous calcium phosphate (ACP) or dicalcium phosphate dihydrate (DCPD, $\left.\mathrm{CaHPO}_{4} \cdot 2 \mathrm{H}_{2} \mathrm{O}\right)$ ) precipitate first $[7,12,32,33]$. The SI values were calculated using the initial concentrations. The concentration of $\mathrm{Mg}^{2+}$ was defined by the total $\mathrm{Mg}$ potentially dissolved. The concentration of carbonates adjusted the charge balance. When $\mathrm{SI}>0$ ( $>0.5$ with the security margin [28]), the supersaturation is reached and minerals are able to precipitate.

\section{Results and discussions}

The experimental design evaluates the influence of process parameters on P-recovery as large struvite crystals.

In each run, the molar balances were controlled for phosphorus, nitrogen, calcium and magnesium. Each molar balance was a sum of 4 or 5 analytical data. The ammonia volatilization was calculated thanks to the liquid/solid molar balance for ammonium (12) in part 3.1.3. Errors in molar balance were below the sum of experimental errors.

\subsection{Phosphate removal considering ammonia volatilization}

3.1.1. Phosphate removal is mainly influenced by stirring rate and addition of $\mathrm{MgO}$

The evolution of the phosphate concentration follows a first order kinetic (9) [34].

$-\frac{\mathrm{d}\left[\mathrm{PO}_{4}-\mathrm{P}\right]_{\mathrm{t}}}{\mathrm{dt}}=\mathrm{K}\left(\left[\mathrm{PO}_{4}-\mathrm{P}\right]_{\mathrm{t}}-\left[\mathrm{PO}_{4}-\mathrm{P}\right]_{\mathrm{e}}\right)$ (9).

The expression of $\left[\mathrm{PO}_{4}-\mathrm{P}\right]_{\mathrm{t}}(10)$ is the result of the integration of

$$
\left[\mathrm{PO}_{4}-\mathrm{P}\right]_{\mathrm{t}}=\left(\left[\mathrm{PO}_{4}-\mathrm{P}\right]_{\mathrm{e}}-\left[\mathrm{PO}_{4}-\mathrm{P}\right]_{0}\right) \times\left(1-\mathrm{e}^{-\mathrm{Kt}}\right)+\left[\mathrm{PO}_{4}-\mathrm{P}\right]_{0}
$$

Where $\left[\mathrm{PO}_{4}-\mathrm{P}\right]_{\mathrm{t}}$ is the concentration of the totally dissolved phosphate at $\mathrm{t}$. $\left[\mathrm{PO}_{4}-\mathrm{P}\right]_{0}$ and $\left[\mathrm{PO}_{4}-\mathrm{P}\right]_{e}$ are the concentration before the addition of $\mathrm{MgO}$ and at equilibrium respectively. $\mathrm{K}$ is a kinetic constant. For runs at $10 \mathrm{rpm}$, the concentrations of the final $\mathrm{PO}_{4}-\mathrm{P}$ 


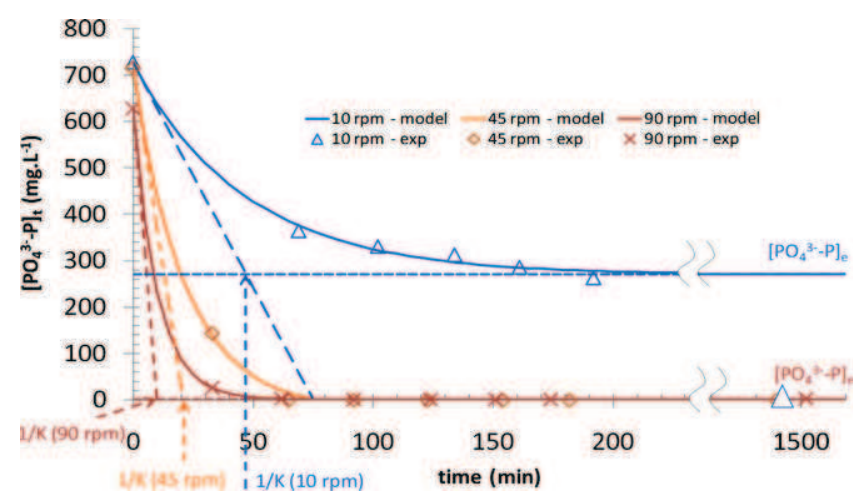

Fig. 1. The evolution of $\mathrm{PO}_{4}{ }^{3-}-\mathrm{P}$ follows a first order kinetic, temperature $=5^{\circ} \mathrm{C}$, initial Mg:Ca $=1.2-1.7,[\mathrm{Mg}-\mathrm{MgO}]=800-1000 \mathrm{mg} \mathrm{L}^{-1}$.

were below the limit calculated by the first order kinetic equation (Fig. 1, $\Delta$ ). At 4 and $24 \mathrm{~h}$, samples were collected for morphogranulometric characterization. The stirring rate was increased during $5 \mathrm{~min}$ in order to collect a homogeneous quote of particles. This stirring perturbed the results of the $10 \mathrm{rpm}$ stirred runs. Therefore, the concentrations of the final $\mathrm{PO}_{4}-\mathrm{P}$ were calculated thanks to the limit of (10) which equals to $\left[\mathrm{PO}_{4}-\mathrm{P}\right]_{e}$. $\left[\mathrm{PO}_{4}-\mathrm{P}\right]_{e}$ was then chosen to evaluate the influence of process parameters on $P$ removal.

Over 48 runs, 44 were described by (10) (mean $R^{2}$ was 0.9998 and standard deviation was $2.47 \mathrm{mg} \mathrm{L}^{-1}$ ). 4 runs were described by an affine function because the concentrations of $\mathrm{PO}_{4}-\mathrm{P}$ at $30 \mathrm{~min}$ were below the quantification limit $\left(10 \mathrm{mg} \mathrm{L}^{-1}\right)$ and more than two points are needed to evaluate $\left[\mathrm{PO}_{4}-\mathrm{P}\right]_{\mathrm{e}}$. Therefore, the study was performed on the 44 runs described by (10).

After the addition of $\mathrm{MgO}$ in the beakers, the $\mathrm{pH}$ value increased from 4.5 to $7-8$ in the first min. The $\mathrm{pH}$ values remained at 7-8 during 15-25 minutes. Afterward it increased from 7-8 to 9-10. For the runs at $5{ }^{\circ} \mathrm{C}$, it remained constant until the end of the runs. For the runs at $20^{\circ} \mathrm{C}$ and $35^{\circ} \mathrm{C}$, the pH decreased slightly by 0.5 to 1 unit after $12 \mathrm{~h}$ (Fig. 2). The temperature and the concentration of $\mathrm{Mg}^{2+}$ remaining as $\mathrm{MgO}$ ([Mg-MgO]) influenced the final $\mathrm{pH}$ values. Final $\mathrm{pH}$ was about $10-10.5$ with $800 \mathrm{mg} \mathrm{L}^{-1}$ of $[\mathrm{Mg}-$ $\mathrm{MgO}$ at $5^{\circ} \mathrm{C}$, about 9.5 with $1050 \mathrm{mg} \mathrm{L}^{-1}$ at $20^{\circ} \mathrm{C}$ and about 9 with $1700 \mathrm{mg} \mathrm{L}^{-1}$ at $35^{\circ} \mathrm{C}$ (Fig. 3). The final pH value depends on various phenomena, $\mathrm{NH}_{3}$ volatilization, incorporation of carbonates, $\mathrm{MgO}$ dissolution. .., which were dependent on the five process parameters studied.

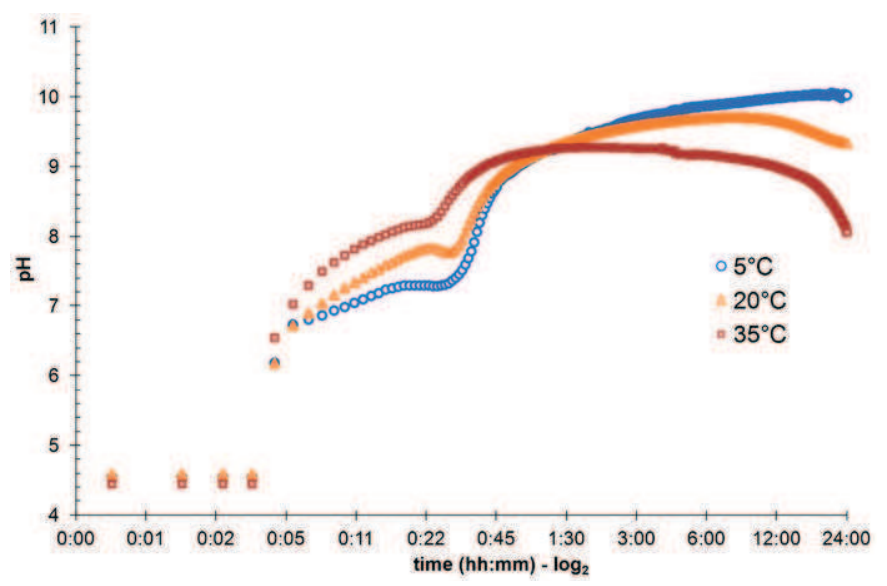

Fig. 2. The pH function of logarithm base 2 of the time evolved differently function of temperature $-5^{\circ} \mathrm{C}$ run $10,20^{\circ} \mathrm{C}$ run $30,35^{\circ} \mathrm{C}$ run 42 .

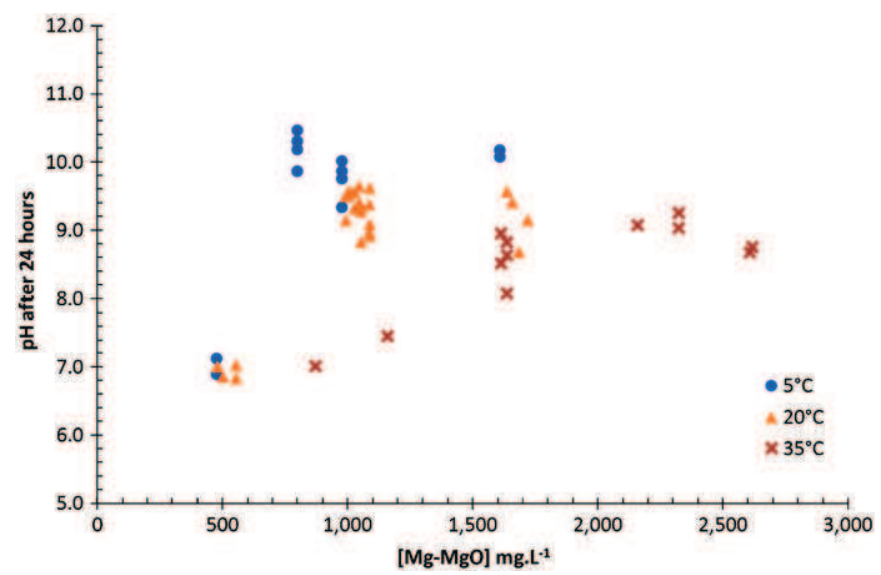

Fig. 3. The final $\mathrm{pH}$ is strongly related to [Mg-MgO] and to the temperature. $\mathrm{pH}$ reaches its maximum with $800 \mathrm{mg} \mathrm{L}^{-1}$ of $\left[\mathrm{Mg}-\mathrm{MgO}\right.$ ] at $5^{\circ} \mathrm{C}$, with $1050 \mathrm{mg} \mathrm{L}^{-1}$ at $20^{\circ} \mathrm{C}$ and with $1700 \mathrm{mg} \mathrm{L}^{-1}$ at $35^{\circ} \mathrm{C}$.

Table 4

ANOVA for the final concentration of phosphates.

\begin{tabular}{ll}
\hline Process parameters & Prob. $>$ F for $\left[\mathrm{PO}_{4}-\mathrm{P}\right]_{\mathrm{e}}$ \\
\hline Adjusted $R^{2}$ & $66.28 \%$ \\
$\mathrm{~A}:$ Stirring rate & $0.0003(-)$ \\
$\mathrm{B}: T e m p e r a t u r e$ & $0.2083(-)$ \\
$\mathrm{D}:$ initial $\mathrm{Mg}^{2+}: \mathrm{Ca}^{2+}$ molar ratio & $0.2158(-)$ \\
$\mathrm{E}: \mathrm{Mg}^{2+}$ as MgO & $0.0000(-)$ \\
$\mathrm{AA}$ & $0.0002(+)$ \\
$\mathrm{AB}$ & $0.0005(+)$ \\
$\mathrm{EE}$ & $0.0000(+)$ \\
\hline
\end{tabular}

$(+)$ indicates a positive influence and $(-)$ a negative influence on the studied responses.

[Mg-MgO] and stirring rate were the leading process parameters which had a negative influence on $\left[\mathrm{PO}_{4}-\mathrm{P}\right]_{\mathrm{e}}$ and consequently a positive influence on $\mathrm{P}$ removal (Table 4 ).

The interaction between the temperature and stirring rate was significant. Whatever the stirring rate, $\mathrm{P}$ was entirely removed at the end of the experiments at $35^{\circ} \mathrm{C}$, while $\left[\mathrm{PO}_{4}-\mathrm{P}\right]_{\mathrm{e}}$ was up to $450 \mathrm{mg} \mathrm{L}^{-1}$ at $5^{\circ} \mathrm{C}$ and a stirring rate of $10 \mathrm{rpm}$ (Fig. 4).

When the stirring rate was at $10 \mathrm{rpm}$, the $\mathrm{MgO}$ settled and only the surface of $\mathrm{MgO}$ could react. The crystallization of struvite was lowered and the $\mathrm{pH}$ did not increase. This effect was partially counterbalanced by the increase of temperature that improved the diffusion and the dissolution of $\mathrm{MgO}$ in the medium. Therefore,

$\mathrm{N}: \mathrm{P}=3,0$, Initial Mg:Ca=1,0,[Mg-MgO] $(\mathrm{mg} \cdot \mathrm{L}-1)=1500,0$

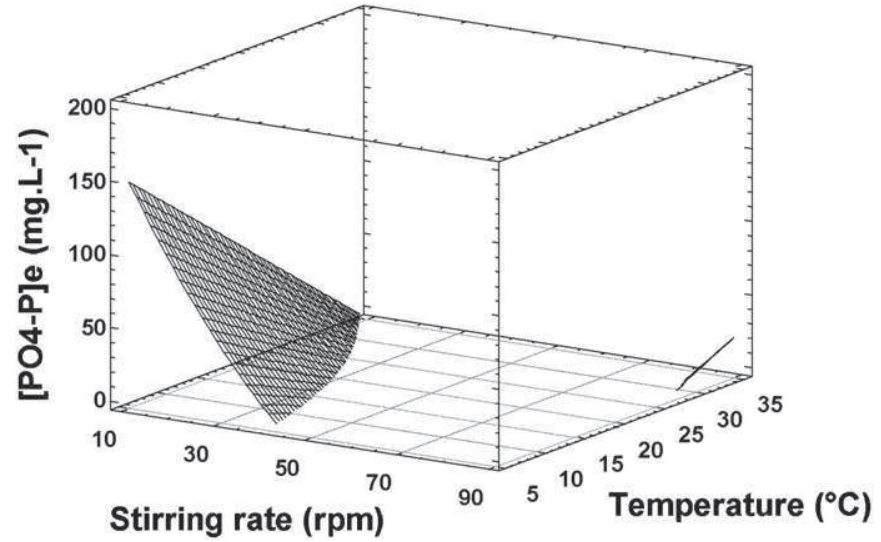

Fig. 4. Temperature and stirring rate negatively influence the final dissolved phosphate $\left[\mathrm{PO}_{4}{ }^{3-}-\mathrm{P}\right]_{\mathrm{e}}$, the grid represents the surface response of the statistical model. 
Temperature $\left({ }^{\circ} \mathrm{C}\right)=15,0, \mathrm{~N}: \mathrm{P}=3,0$, Initial $\mathrm{Mg}: \mathrm{Ca}=1,0$

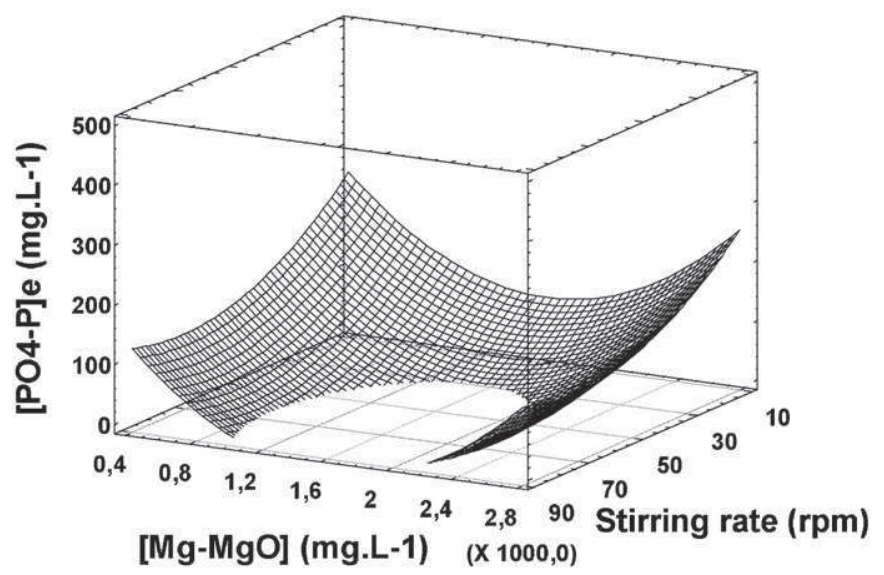

Fig. 5. $[\mathrm{Mg}-\mathrm{MgO}]$ and stirring rate negatively influence the final dissolved phosphate $\left[\mathrm{PO}_{4}{ }^{3-}-\mathrm{P}\right]_{\mathrm{e}}$, the grid represents the surface response of the statistical model.

$\left[\mathrm{PO}_{4}-\mathrm{P}\right]_{\mathrm{e}}$ remained high for the $10 \mathrm{rpm}$ stirred runs (Fig. 5). The positive effect of the concentration of magnesium was also observed in literature with the addition of $\mathrm{Mg}(\mathrm{OH})_{2}$ [25] or $\mathrm{MgCl}_{2}$ plus $\mathrm{NaOH}$ [15].

\subsubsection{Phosphate removal as struvite is mainly influenced by $N: P$} ratio

P was supposed to form either struvite or calcium phosphate which was confirmed by Raman analysis (part 3.3.3). The percentage of phosphate as struvite is calculated according to (11) where $\mathrm{M}_{\mathrm{N}}$ and $\mathrm{M}_{\mathrm{P}}$ are the molecular mass of nitrogen and phosphorus respectively. $\left[\mathrm{NH}_{3}-\mathrm{N}\right]_{\text {volatilized }}$ is calculated using (12) in part 3.1.3.

$$
\begin{aligned}
& \% \mathrm{PO}_{4}-\mathrm{P}_{\text {Struvite }} \\
& =\frac{\left(\left[\mathrm{NH}_{4}-\mathrm{N}\right]_{\text {initial }}-\left[\mathrm{NH}_{4}-\mathrm{N}\right]_{\text {final }}-\left[\mathrm{NH}_{3}-\mathrm{N}\right]_{\text {volatilized }}\right) \times \mathrm{M}_{\mathrm{P}}}{\mathrm{M}_{\mathrm{N}} \times\left[\mathrm{PO}_{4}-\mathrm{P}\right]_{\text {initial }}}
\end{aligned}
$$

The ANOVA in Table 5 indicates that N:P molar ratio $(\mathrm{p}<0.0001)$ and temperature $(p<0.01)$ were the leading process parameters that influenced the proportion of $\mathrm{P}$ as struvite.

$\% \mathrm{PO}_{4}-\mathrm{P}_{\text {Struvite }}$ increased from $20 \%$ to $90 \%$ with an increase in $\mathrm{N}: \mathrm{P}$ molar ratio from 1 to 3. Abbona et al. [13] showed that a high $\mathrm{Mg}: \mathrm{Ca}$ ratio (4:1) combined with a low $\mathrm{pH}$ (around 7) improved struvite formation over calcium phosphate formation. In this experimental design, the minimum $\mathrm{Mg}$ :Ca molar ratio was set at 2.25 to increase the $\mathrm{pH}$ value to at least 7. It appeared that above this ratio, the $\mathrm{Mg}: \mathrm{Ca}$ molar ratio was not the limiting factor to struvite formation, it was the $\mathrm{N}: \mathrm{P}$ molar ratio.

There are two possible explanations for the influence of the N:P molar ratio on the proportion of $\mathrm{P}$ as struvite. Firstly, $\mathrm{NH}_{4}{ }^{+}$participates to struvite precipitation: the supersaturation increased with

Table 5

ANOVA for the proportion of $\mathrm{P}$ as struvite $\left(\% \mathrm{PO}_{4}-\mathrm{P}\right.$ as struvite).

\begin{tabular}{ll}
\hline Process parameters & Prob. $>\mathrm{F}$ for $\% \mathrm{PO}_{4}-\mathrm{P}$ as struvite \\
\hline Adjusted $R^{2}$ & $65.27 \%$ \\
B: Temperature & $0.0089(-)$ \\
C: N:P molar ratio & $0.0000(+)$ \\
BB & $0.0740(-)$ \\
BC & $0.1000(-)$ \\
CC & $0.0472(-)$
\end{tabular}

$(+)$ indicates a positive influence and (-) a negative influence on the studied responses.
Table 6

ANOVA for the percentage of ammonia volatilization.

\begin{tabular}{lc}
\hline Process parameters & Prob. $>\mathrm{F}$ for $\% \mathrm{NH}_{3}$ volatilization \\
\hline Adjusted $R^{2}$ & $87.28 \%$ \\
$\mathrm{~B}:$ Temperature & $0.0006(+)$ \\
$\mathrm{E}: \mathrm{Mg}^{2+}$ as $\mathrm{MgO}$ & $0.0000(+)$ \\
$\mathrm{BB}$ & $0.0005(-)$ \\
$\mathrm{BE}$ & $0.0004(+)$ \\
$\mathrm{EE}$ & $0.0002(-)$ \\
\hline
\end{tabular}

$(+)$ indicates a positive influence and $(-)$ a negative influence on the studied responses.

the $\mathrm{N}: \mathrm{P}$ molar ratio and the nucleation rate of struvite was speeded up (1). Secondly, $\mathrm{NH}_{4}{ }^{+}$improves the buffer capacity of the solution $[18,35,36]$. The nucleation of struvite occurs at a lower $\mathrm{pH}$ than the one needed for the precipitation of calcium phosphate [13]. Consequently, struvite precipitation is favoured by a high concentration of $\mathrm{NH}_{4}{ }^{+}$. However, as struvite precipitates, $\mathrm{NH}_{4}{ }^{+}$buffering capacity decreases. Therefore, the effect of $\mathrm{N}: \mathrm{P}$ molar ratio on the buffering capacity cannot be observed just by monitoring the $\mathrm{pH}$.

$\% \mathrm{PO}_{4}-\mathrm{P}_{\text {Struvite }}$ decreased from $80 \%$ to $50 \%$ when temperature rose from 5 to $35^{\circ} \mathrm{C}$.

With high temperature, the pKa of $\mathrm{NH}_{4}{ }^{+} / \mathrm{NH}_{3}$ decreases favouring the $\mathrm{NH}_{3}$ form and $\mathrm{NH}_{3}$ volatilization as described below. Therefore the supersaturation of struvite decreases and the phosphates are able to precipitate as calcium phosphate.

\subsubsection{Ammonia volatilization is mainly influenced by temperature and addition of $\mathrm{MgO}$}

Molar balance for nitrogen highlighted a strong ammonia volatilization at the end of the runs. For each run, total ammonia volatilization was calculated using (12).

$$
\begin{aligned}
{\left[\mathrm{NH}_{3}-\mathrm{N}\right]_{\text {volatilized }}=} & {\left[\mathrm{NH}_{4}^{+}-\mathrm{N}\right]_{\text {initial in liquid }}-\left[\mathrm{NH}_{4}^{+}-\mathrm{N}\right]_{\text {final in liquid }} } \\
& -\left[\mathrm{NH}_{4}^{+}-\mathrm{N}\right]_{\text {final in solid }}
\end{aligned}
$$

[Mg-MgO] and temperature $(\mathrm{p}<0.0001)$ were the leading process parameters which influenced ammonia volatilization (Table 6).

The interaction between temperature and [ $\mathrm{Mg}-\mathrm{MgO}]$ was significant. Whatever concentration [Mg-MgO] had at $5^{\circ} \mathrm{C}, \mathrm{NH}_{3}$ volatilization was below $10 \%$ at the end of the experiments, while the effect of [Mg-MgO] was high at high temperature (Fig. 6).

In literature, ammonia volatilization is function of $\mathrm{pH}$, temperature and ammonium concentration [37]. In this experimental

Stirring rate $(\mathrm{rpm})=60,0, \mathrm{~N}: \mathrm{P}=3,0$, Initial $\mathrm{Mg}: \mathrm{Ca}=1,0$

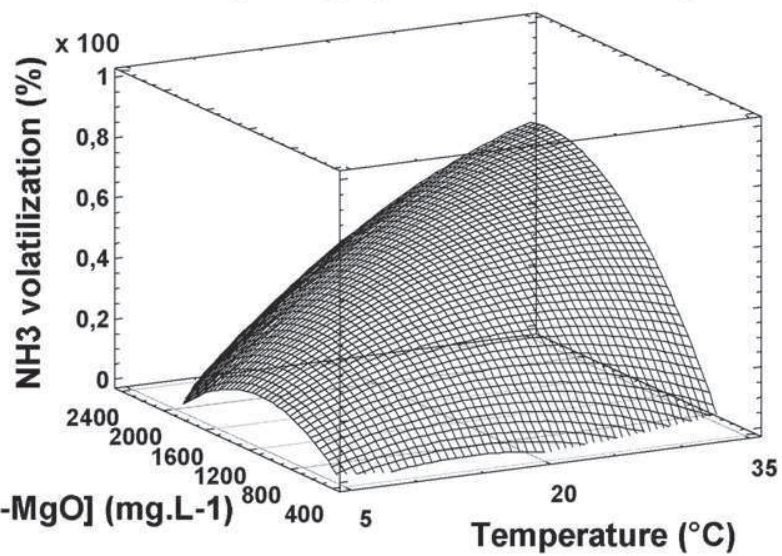

Fig. 6. [Mg-MgO] and temperature positively influence total $\mathrm{NH}_{3}$ volatilization, the grid represents the surface response of the statistical model. 


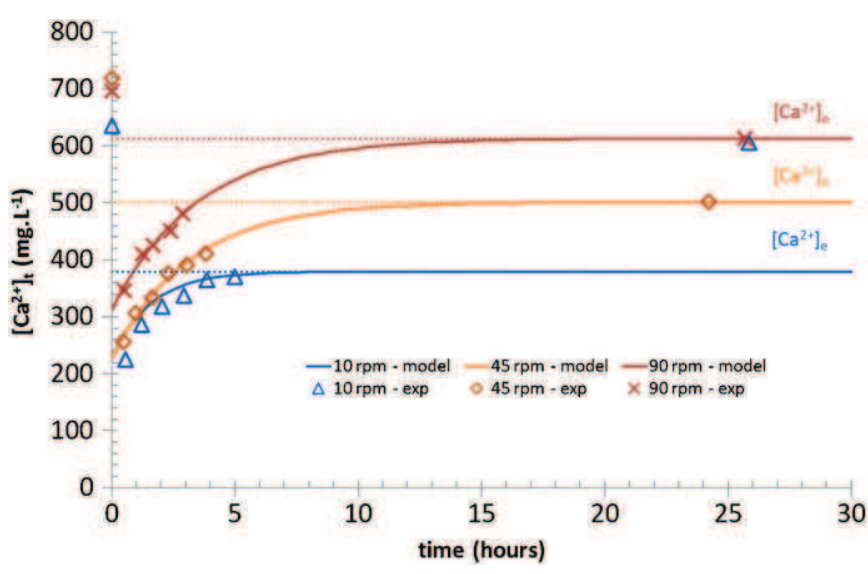

Fig. 7. Calcium apparent dissolution follows a first order kinetic, temperature $=20^{\circ} \mathrm{C}, \mathrm{N}: \mathrm{P}=3$, initial $\mathrm{Mg}: \mathrm{Ca}=1.0-1.2,[\mathrm{Mg}-\mathrm{MgO}]=1000-1600 \mathrm{mg} \mathrm{L}^{-1}$.

design, initial N:P molar ratio and stirring rate had no significant influence on ammonia volatilization.

\subsubsection{Phosphate precipitation as calcium phosphates is mainly} influenced by stirring rate and $N: P$ ratio

The calcium precipitation is very complex to explain as it could precipitate in several forms depending on the kinetic of struvite precipitation, $\mathrm{pH}$, supersaturation, temperature...

Further solid analysis needs to be performed hourly to determine exactly the composition of the solid. In these experiments, a large part of the calcium was first removed within $30 \mathrm{~min}$, and then, we observed an apparent dissolution of the removed calcium which followed a first order kinetic (Fig. 7 and (13)).

Over 48 runs, 43 were described by (13) (mean $R^{2}$ was 0.99 and standard deviation was $5.36 \mathrm{mg} \mathrm{L}^{-1}$ ). 5 runs were excluded from the statistical analysis because there was no apparent dissolution of the calcium.

$\left[\mathrm{Ca}^{2+}\right]_{\mathrm{t}}=\left(\left[\mathrm{Ca}^{2+}\right]_{\mathrm{e}}-\left[\mathrm{Ca}^{2+}\right]_{0}\right) \times\left(1-\mathrm{e}^{-\mathrm{Kt}}\right)+\left[\mathrm{Ca}^{2+}\right]_{0}$

$\left[\mathrm{Ca}^{2+}\right]_{\mathrm{t}}$ and $\left[\mathrm{Ca}^{2+}\right]_{\mathrm{e}}$ are the concentration of the calcium totally dissolved at $t$ and at equilibrium respectively. $\left[\mathrm{Ca}^{2+}\right]_{0}$, the concentration when time equals $0 \mathrm{~h}$, has no chemical reality. $\mathrm{K}$ is the kinetic constant of dissolution.

The N:P molar ratio and stirring rate were the leading parameters that influenced $\left[\mathrm{Ca}^{2+}\right]_{\mathrm{e}}$ (Table 7 and Fig. 8).

When stirring rate was below $10 \mathrm{rpm}$, precipitations or dissolutions of calcium phosphate and struvite and $\mathrm{MgO}$ were diffusion controlled $[7,8]$. Therefore, low stirring rates slowed down, or even prevented the dissolution of calcium phosphate.

Table 7A

ANOVA for the concentration of calcium at equilibrium.

\begin{tabular}{lc}
\hline Process parameters & Prob. $>\mathrm{F}$ for $\left[\mathrm{Ca}^{2+}\right]_{\mathrm{e}}$ \\
\hline Adjusted $R^{2}$ & $70.67 \%$ \\
A:Stirring rate & $0.0003(+)$ \\
B:Temperature & $0.0152(-)$ \\
$\mathrm{C}: \mathrm{N}: P$ molar ratio & $0.0000(+)$ \\
D:initial $\mathrm{Mg}^{2+}: \mathrm{Ca}^{2+}$ molar ratio & $0.4254(-)$ \\
E: $\mathrm{Mg}^{2+}$ as MgO & $0.0093(-)$ \\
$\mathrm{AA}$ & $0.0006(-)$ \\
BB & $0.0000(+)$ \\
BD & $0.0075(-)$ \\
CD & $0.0171(+)$ \\
DD & $0.0115(-)$ \\
\hline
\end{tabular}

$(+)$ indicates a positive influence and $(-)$ a negative influence on the studied responses.
Table 7B

ANOVA for particles $>100 \mu \mathrm{m}$

\begin{tabular}{lll}
\hline Process parameters & $\begin{array}{l}\text { Prob. }>\text { F for particles }> \\
100 \mu \mathrm{m}(\mathrm{g} / \mathrm{L})\end{array}$ & $\begin{array}{l}\text { Prob. }>\text { F for \% particles } \\
>100 \mu \mathrm{m}\end{array}$ \\
\hline Adjusted $R^{2}$ & $69.43 \%$ & $72.36 \%$ \\
A: Stirring rate & & $0.3431(+)$ \\
B: Temperature & $0.0062(-)$ & $0.0460(-)$ \\
C: N:P molar ratio & $0.0029(+)$ & $0.0361(+)$ \\
E: $\mathrm{Mg}^{2+}$ as MgO & $0.0000(-)$ & $0.0000(-)$ \\
AE & & $0.0474(-)$ \\
EE & $0.0000(+)$ & $0.0000(+)$ \\
\hline
\end{tabular}

$(+)$ indicates a positive influence and $(-)$ a negative influence on the studied responses.

The influence of $\mathrm{N}: \mathrm{P}$ molar ratio on $\left[\mathrm{Ca}^{2+}\right]_{\mathrm{e}}$ confirms the previous results: high $\mathrm{N}: \mathrm{P}$ molar ratio improved struvite precipitation instead of calcium phosphate precipitation.

\subsection{Influence of process parameters on dried products}

The three solid fractions ( $<25 \mu \mathrm{m}, 25-100 \mu \mathrm{m}$ and $>100 \mu \mathrm{m}$ ) were weighed and analyzed by ion chromatography after acid dissolution and by Raman spectroscopy.

In order to assess mass balance in dried solids, phosphates are considered as struvite and ACP (part 3.3), calcium was thought to precipitate as ACP and $\mathrm{CaCO}_{3}$ and magnesium was considered as $\mathrm{MgO}$ and struvite (14). As runs were all carried out in an open beaker, carbonate was either incorporated to the crystals or precipitated as calcite [38]. The linear formula used for ACP was $\mathrm{Ca}_{2} \mathrm{P}_{2} \mathrm{O}_{7} \cdot \mathrm{H}_{2} \mathrm{O}$.

$$
\begin{aligned}
\mathrm{m}_{\text {dried solid }}= & \mathrm{m}_{\mathrm{MgO}}+\mathrm{m}_{\text {Struvite }}+\mathrm{m}_{\mathrm{ACP}}+\mathrm{m}_{\mathrm{CaCO}_{3}}+\mathrm{m}_{\mathrm{Na}^{+}}+\mathrm{m}_{\mathrm{K}^{+}} \\
& +\mathrm{m}_{\mathrm{Cl}^{-}}+\mathrm{m}_{\mathrm{NO}_{2}^{-}}+\mathrm{m}_{\mathrm{NO}_{3}^{-}}+\mathrm{m}_{\mathrm{SO}_{4}^{2-}}
\end{aligned}
$$

For $80 \%$ of the runs, the absolute error on mass balance was below the sum of experimental errors (20\%). These results confirmed the hypothesis that calcium could precipitate as ACP and as calcium carbonate. The absolute error on mass balance was significant in a third of the fine particles and in a fifth of the particles $>100 \mu \mathrm{m}$ obtained at $35^{\circ} \mathrm{C}$. The Raman analyses (3.3.3) show that magnesium precipitated as $\mathrm{Mg}(\mathrm{OH})_{2}$ (brucite) instead of remaining as $\mathrm{MgO}$ in small particles or instead of $\mathrm{CaCO}_{3}$ in large particles.

\section{Temperature $\left({ }^{\circ} \mathrm{C}\right)=15,0$, Initial $\mathrm{Mg}: \mathrm{Ca}=1,0,[\mathrm{Mg}-\mathrm{MgO}]$ (mg.L-1) $=\mathbf{4 7 5 , 0}$}

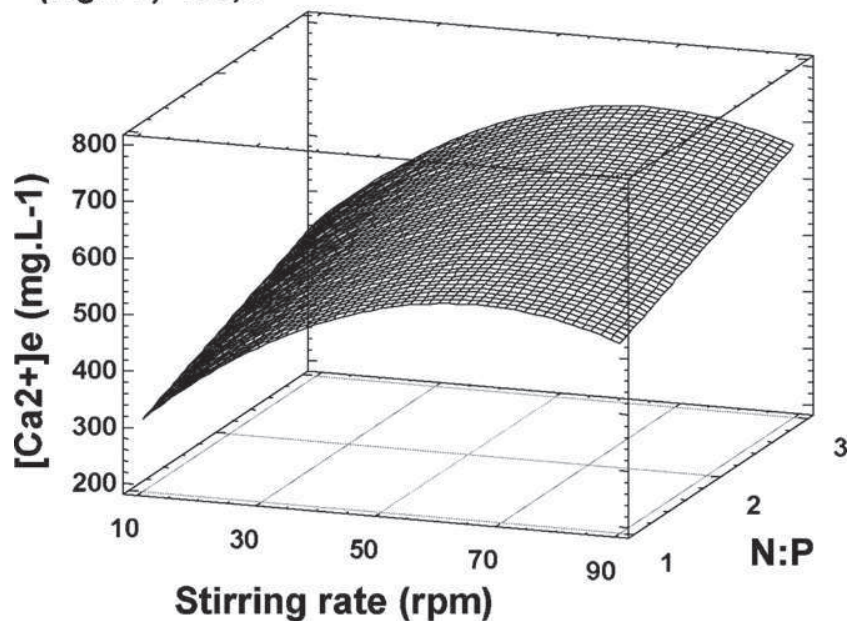

Fig. 8. Stirring rate and N:P molar ratio positively influence $\left[\mathrm{Ca}^{2+}\right]_{e}$, the grid represents the surface response of the statistical model. 


\section{Stirring rate $(\mathrm{rpm})=60,0, \mathrm{~N}: \mathrm{P}=3,0$, Initial $\mathrm{Mg}: \mathrm{Ca}=1,0$}

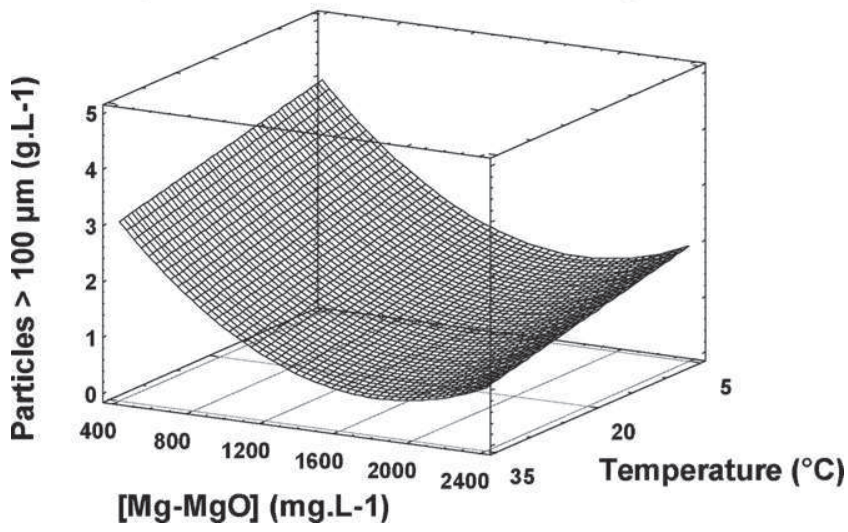

Fig. 9. [Mg-MgO] and temperature negatively influence concentration of particles bigger than $100 \mu \mathrm{m}$, the grid represents the surface response of the statistical model.

\subsubsection{Particles $>100 \mu \mathrm{m}$ are mainly influenced by the addition of $\mathrm{MgO}$}

The influence of process parameters was studied on the fractions $>100 \mu \mathrm{m}$; the filtration of struvite crystals are carried out in filter bags with a $100 \mu \mathrm{m}$ cut-off in the process plant. The ANOVA in Table 7 indicated that $[\mathrm{Mg}-\mathrm{MgO}](\mathrm{p}<0.0001)$, temperature and $\mathrm{N}: \mathrm{P}$ molar ratio were the leading process parameters which influenced the particles $>100 \mu \mathrm{m}$ (Fig. 9).

The struvite growth is assumed to be size dependent [11]: small nuclei produce small crystals ultimately. Moreover, the higher the supersaturation $(\beta)$ is, the smaller nuclei are $[5,7,8]$. Therefore, as high concentrations of $\mathrm{Mg}^{2+}$ increase the supersaturation of struvite, the quantity of fine crystals is increased too. The influence of [Mg-MgO] on the struvite growth is very complex. [Mg-MgO] influenced the $\mathrm{pH}$ (and so the phosphate removal), the concentration of $\mathrm{Mg}^{2+}$ (and so the supersaturation), the crystallization as nucleation of struvite could occur on the particles of MgO. . Further studies are needed to better understand the influence of this parameter on the kinetics.

When temperature rises, the supersaturation of struvite decreases, so the size of the crystals increases [39]. This assertion is true only when $\mathrm{NH}_{4}{ }^{+}$is not a limiting factor in struvite crystallization. Otherwise, as temperature increases, Henry's law constant $\left(\mathrm{K}_{\mathrm{H}}\right)$ and dissociation constant $\left(\mathrm{K}_{\mathrm{a}}\right)$ of ammonia evolve to favour greater $\mathrm{NH}_{3} / \mathrm{NH}_{4}{ }^{+}$ratio in liquid and ammonia volatilization [37]. Therefore, when dissolved $\mathrm{NH}_{4}{ }^{+}$is a limiting factor, $\mathrm{NH}_{3}$ volatilization will slow down struvite crystallization and struvite crystals will dissolve in order to restore the balance to $\mathrm{NH}_{4}{ }^{+}$in the solution. On this account, the temperature has a negative impact on crystal sizes.

The effect of stirring is to maintain $\mathrm{MgO}$ in suspension (interaction $\mathrm{AE}$ ). Without it, the $\mathrm{pH}$ will not rise to the minimal value for $\mathrm{P}$ precipitation. However, high mixing rates have a negative impact on struvite crystal sizes. Two mechanisms could be involved: struvite dissolution or crystal break. As the full amount of struvite did not change, breaking was more probable.

\subsubsection{The proportion of struvite versus calcium phosphate is} mainly influenced by particles size and $N: P$ ratio

The experimental design in Statgraphics software was modified to include the influence of particles size $(<25 \mu \mathrm{m}, 25-100 \mu \mathrm{m}$ or $>100 \mu \mathrm{m}$ ) on the proportion of struvite versus calcium phosphate. $R^{2}$ of statistical model in Table 8 was below $65 \%$ so it was said to only indicate trends.

The ANOVA in Table 8 indicated that particle size $(\mathrm{p}<0.0001)$, $\mathrm{N}: \mathrm{P}$ molar ratio $(\mathrm{p}<0.001)$ and temperature $(\mathrm{p}<0.05)$ were the
Table 8

ANOVA for proportion of struvite versus calcium phosphate in dried solid (\%).

\begin{tabular}{ll}
\hline Process parameters & $\begin{array}{l}\text { Prob. }>\mathrm{F} \text { for proportion of struvite versus } \\
\text { calcium phosphate in dried solid }(\%)\end{array}$ \\
\hline Adjusted $R^{2}$ & $62.78 \%$ \\
B: N:P & $0.0004(+)$ \\
D: [Mg-MgO] & $0.2961(-)$ \\
E: Temperature & $0.0177(-)$ \\
F: Particle size & $0.0000(+)$ \\
BE & $0.0495(+)$ \\
DD & $0.0477(+)$ \\
FF & $0.0000(-)$ \\
\hline
\end{tabular}

$(+)$ indicates a positive influence and $(-)$ a negative influence on the studied responses.

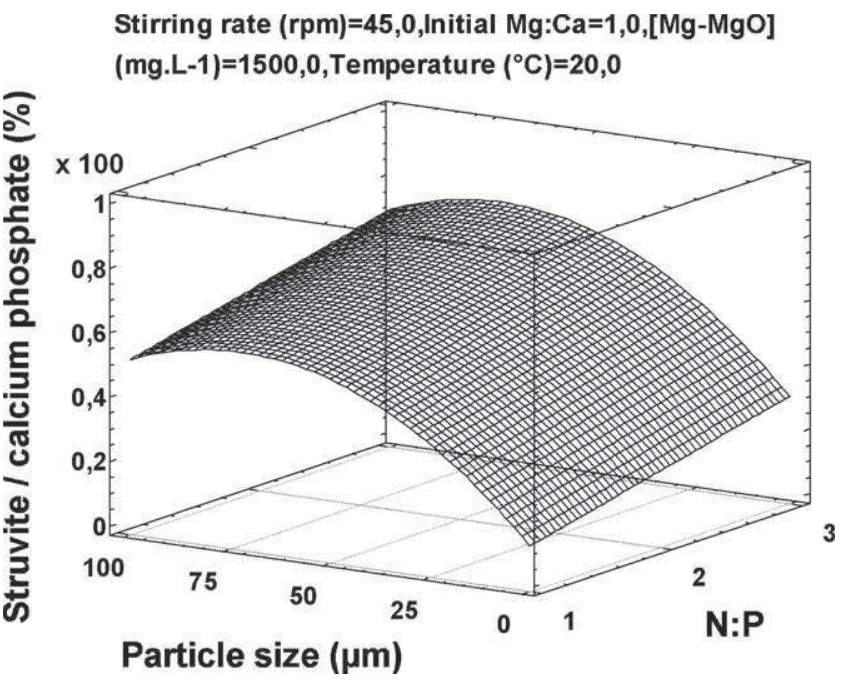

Fig. 10. Particle size and N:P molar ratio positively influence the proportion of struvite versus calcium phosphate in dried solid, the grid represents the surface response of the statistical model.

leading process parameters which influenced the proportion of struvite versus calcium phosphate in dried solids (\%).

Struvite was the main component of the fractions $>25 \mu \mathrm{m}$ for all level of variables (Fig. 10).

The influence of N:P molar ratios on the proportion of struvite versus calcium phosphate confirms the results of the previous part: with a high N:P molar ratio, struvite precipitation was favoured over calcium phosphate precipitation.

\subsection{Analyses of the solid fractions}

\subsubsection{Potential solid phases with PHREEQC®}

The potential final precipitates are defined by a $\mathrm{SI}>0.5$; the $\mathrm{SI}$ values for the 48 runs are given in Table 10 . ACP, calcite and struvite could precipitate in all the runs. Brucite, brushite, calcium and magnesium phosphate could precipitate in most of the runs as shown in Table 11. Hydromagnesite and artinite could precipitate, but, in literature, there were either not observed in association with struvite precipitation or they could only biomineralize with the help of bacteria $[40,41]$.

\subsubsection{Calcium phosphate precipitates as ACP}

The forms of calcium phosphate precipitated were determined by calculating the Ca:P molar ratio in the three solid fractions using (15):

Ca $: P=\frac{\text { Caprecipitated }}{\mathrm{P}_{\text {Precipitated }}-\mathrm{N}_{\text {Precipitated }}}$ 
Table 10A

SI values for the potential precipitates after $24 \mathrm{~h}$ for the 48 runs.

\begin{tabular}{|c|c|c|c|c|c|}
\hline Minerals & Formula & Min & Max & Median & $\mathrm{Nb}$ run $\mathrm{SI}>0.5$ \\
\hline $\mathrm{pH}$ & & 6.84 & 10.47 & 9.20 & \\
\hline Temperature $\left({ }^{\circ} \mathrm{C}\right)$ & & 5.00 & 35.00 & 20.00 & \\
\hline Artinite & $\mathrm{MgCO}_{3} \cdot \mathrm{Mg}(\mathrm{OH})_{2} \cdot 3 \mathrm{H}_{2} \mathrm{O}$ & -7.12 & 3.18 & 1.64 & 36 \\
\hline Brucite & $\mathrm{Mg}(\mathrm{OH})_{2}$ & -0.84 & 6.51 & 5.26 & 42 \\
\hline Brushite (DCPD) & $\mathrm{CaHPO}_{4} \cdot 2 \mathrm{H}_{2} \mathrm{O}$ & 0.12 & 1.00 & 0.58 & 38 \\
\hline Calcium phosphate & $\mathrm{CaHPO}_{4}$ & 0.40 & 1.36 & 0.80 & 46 \\
\hline Calcite & $\mathrm{CaCO}_{3}$ & 0.63 & 3.09 & 2.76 & 48 \\
\hline Calcite hydrate & $\mathrm{CaCO}_{3} \cdot \mathrm{H}_{2} \mathrm{O}$ & -0.71 & 1.75 & 1.42 & 40 \\
\hline Hydromagnesite & $\mathrm{Mg}_{5}\left(\mathrm{CO}_{3}\right)_{4}(\mathrm{OH})_{2} \cdot 4 \mathrm{H}_{2} \mathrm{O}$ & -12.62 & 8.83 & 4.71 & 40 \\
\hline K-Struvite & $\mathrm{MgKPO}_{4} \cdot 6 \mathrm{H}_{2} \mathrm{O}$ & -2.09 & 1.06 & 0.47 & 26 \\
\hline Magnesium phosphate & $\mathrm{Mg}_{3}\left(\mathrm{PO}_{4}\right)_{2}$ & -1.28 & 5.29 & 4.03 & 41 \\
\hline Newberyite & $\mathrm{MgHPO}_{4} \cdot 3 \mathrm{H}_{2} \mathrm{O}$ & -0.33 & 0.64 & 0.26 & 10 \\
\hline Struvite & $\mathrm{MgNH}_{4} \mathrm{PO}_{4} \cdot 6 \mathrm{H}_{2} \mathrm{O}$ & 0.47 & 3.07 & 2.52 & 48 \\
\hline $\mathrm{ACP}$ & $\mathrm{Ca}_{3}\left(\mathrm{PO}_{4}\right)_{2} \cdot \mathrm{xH}_{2} \mathrm{O}$ & 1.33 & 6.74 & 5.42 & 48 \\
\hline
\end{tabular}

Table 10B

Ca:P molar ratio in various calcium phosphates precipitates [45].

\begin{tabular}{|c|c|c|c|}
\hline Ca:P molar ratio & Name & Formula & $\begin{array}{l}\text { pH stability range in } \\
\text { aqueous solutions at } 25^{\circ}\end{array}$ \\
\hline 1.00 & Brushite & $\mathrm{CaHPO}+2 \mathrm{H}_{2} \mathrm{O}$ & $2.0-6.0$ \\
\hline 1.33 & Octacalcium phosphate & $\mathrm{Ca}_{8}\left(\mathrm{HPO}_{4}\right)_{2}\left(\mathrm{PO}_{4}\right)_{4} \cdot 5 \mathrm{H}_{2} \mathrm{O}$ & $5.5-7.0$ \\
\hline $1.00-2.20$ & $\mathrm{ACP}$ & $\mathrm{Ca}_{x} \mathrm{H}_{y}\left(\mathrm{PO}_{4}\right)_{z} \cdot n \mathrm{H}_{2} \mathrm{O}$ & $5.0-12.0$ \\
\hline $1.50-1.67$ & Calcium-deficient hydroxyapatite & $\mathrm{Ca}_{10-x}\left(\mathrm{HPO}_{4}\right)_{x}\left(\mathrm{PO}_{4}\right)_{6-x}(\mathrm{OH})_{2-x}$ & $6.5-9.5$ \\
\hline 1.67 & Hydroxyapatite & $\mathrm{Ca}_{10}\left(\mathrm{PO}_{4}\right)_{6}(\mathrm{OH})_{2}$ & $9.5-12.0$ \\
\hline
\end{tabular}

Where $\mathrm{Ca}_{\text {Precipitated }}, \mathrm{P}_{\text {Precipitated }}$ and $\mathrm{N}_{\text {Precipitated }}$ are the calcium, phosphorus and nitrogen precipitated in mol.g ${ }^{-1}$ of solidrespectively. Nitrogen is assumed to only precipitate as struvite.

In the fractions $<25 \mu \mathrm{m}, \mathrm{Ca}$ :P molar ratio was near 0.90 which indicates the possible presence of brushite or ACP (Table 10). The form of calcium phosphate was probably ACP as the minimum $\mathrm{pH}$ values of the runs were higher than 6.0. The literature confirms the result that ACP co-precipitates with struvite $[14,19,21,42,43]$. The incorporation of $\mathrm{Mg}^{2+}$ into the structure of ACP could explained why the Ca:P molar ratio was inferior to 1 and why ACP particles were mainly in the fraction $<25 \mu \mathrm{m}[12,32]$.

In the fractions $>25 \mu \mathrm{m}$, Ca:P molar ratios were below 0.7. Calcium might be incorporated in struvite structure.

Ca:P molar ratio was higher than 1.2 for the majority of the fractions $>100 \mu \mathrm{m}$ and obtained at $35^{\circ} \mathrm{C}$. Raman spectrum for these fractions showed the characteristic peaks of $\mathrm{CaCO}_{3}$ (Fig. 11, part 3.3.3). Moreover, the Fig. 2 in part 3.1.1 shows that the $\mathrm{pH}$ values decreased after $12 \mathrm{~h}$ in the runs at $35^{\circ} \mathrm{C}$. The precipitation of $\mathrm{CaCO}_{3}$ could explain this decrease [44].

\subsubsection{Solid analyses by Raman spectroscopy}

Calcite, calcium phosphate, $\mathrm{HAP}, \mathrm{MgCO}_{3}$, magnesium phosphate, newberyite, brucite, MgO, ammonium phosphate and struvite (analytic grade) were analyzed by Raman spectroscopy to have reference spectra.

The Raman spectrum for struvite showed two main peaks for phosphate vibrations, one at $950 \mathrm{~cm}^{-1}$ (total symmetric stretching mode of $-\mathrm{PO}_{4}$ ) and one at $565 \mathrm{~cm}^{-1}\left(v_{4}\right.$ antisymmetric bend mode of $-\mathrm{PO}_{4}$ ) and two peaks corresponding to ammonium vibrations, one at $1440 \mathrm{~cm}^{-1}\left(v_{4}\right.$ mode of $\left.-\mathrm{NH}_{4}\right)$ and one at $1700 \mathrm{~cm}^{-1}\left(v_{2}\right.$ mode of
$-\mathrm{NH}_{4}$ ) (spectrum (f) in Fig. 11). These Raman shifts are in line with literature results $[38,46-48]$.

Presence, absence and height ratio of these four peaks indicate whether the product mainly contains struvite or not.

The Raman spectrum for brucite showed 3 characteristic peaks: 3 strong bands at 278, 443 (symmetric $\mathrm{E}_{\mathrm{g}}$ and $\mathrm{A}_{1 \mathrm{~g}}$ stretching mode) and $1085 \mathrm{~cm}^{-1}$ and one broad peak at $1044 \mathrm{~cm}^{-1}$ which is coherent with literature [49].

The Raman spectra of the solid fractions confirmed the results of Table 10. ACP, struvite and brucite were the main component of the fractions $<25 \mu \mathrm{m}$ (spectrum (a) in Fig. 11 and in Table 11).

At 5 and $20^{\circ} \mathrm{C}$, struvite was the main component of the fractions $>25 \mu \mathrm{m}$ (spectra (d) and (e) in Fig. 11 and in Table 11 ). At $20^{\circ} \mathrm{C}$, the composition of the fractions $>100 \mu \mathrm{m}$ depended on other process parameters rather than on particles size or temperature (spectra (c) in Fig. 11).

At $35^{\circ} \mathrm{C}$ the main compound was not struvite which was in line with solid dissolution analysis.

It is noticeable that the spectrum at $5{ }^{\circ} \mathrm{C}$ for fine particles (a) was similar to the spectrum at $35^{\circ} \mathrm{C}$ for particles $>100 \mu \mathrm{m}$ (b). Those spectra presented three characteristic peaks of carbonate precipitation: one at $1080 \mathrm{~cm}^{-1}\left(\nu_{1}\right.$ symmetric stretch mode of $\left.-\mathrm{CO}_{3}\right)$, a broad one at $715 \mathrm{~cm}^{-1}\left(v_{2}\right.$ mode of $\left.-\mathrm{CO}_{3}\right)$ [50] and one at $2906 \mathrm{~cm}^{-1}$ (could be attributed to $\mathrm{CaCO}_{3}$ ). Compared to struvite spectrum, peaks at $435 \mathrm{~cm}^{-1}\left(\nu_{2}\right.$ symmetric bend mode of $-\mathrm{PO}_{4}$ ) shifted by $+15 \mathrm{~cm}^{-1}$ which could indicate the presence of calcium phosphate [51]. The feature peaks at 278, and $442 \mathrm{~cm}^{-1}$ could also indicate the presence of brucite [49]. The main peak at $945 \mathrm{~cm}^{-1}$ either was very low or had vanished. Moreover, two peaks appeared one at $1050 \mathrm{~cm}^{-1}\left(\nu_{3}\right.$ antisymmetric stretch mode

Table 11

Struvite is the main component of particles $>25 \mu \mathrm{m}$ obtained at 5 and $20^{\circ} \mathrm{C}$.

\begin{tabular}{|c|c|c|c|c|c|c|c|c|c|}
\hline $\begin{array}{l}\text { Temperature } \\
\left({ }^{\circ} \mathrm{C}\right)\end{array}$ & & $5^{\circ} \mathrm{C}$ & & & $20^{\circ} \mathrm{C}$ & & & $35^{\circ} \mathrm{C}$ & \\
\hline $\begin{array}{l}\text { Particles size } \\
\qquad(\mu \mathrm{m})\end{array}$ & $<25$ & $25-100$ & $>100$ & $<25$ & $25-100$ & $>100$ & $<25$ & $25-100$ & $>100$ \\
\hline Composition & $\mathrm{ACP}=\mathrm{MAP}^{*}>\mathrm{Br}^{*}>$ Calcite & $\mathrm{MAP}>\mathrm{CaP}^{*}=\mathrm{Br}$ & $\mathrm{MAP}>\mathrm{Br}$ & $\mathrm{MAP}>\mathrm{ACP}>\mathrm{Br}$ & $\mathrm{MAP}>\mathrm{Br}$ & $\mathrm{MAP}>\mathrm{Br}$ & $\mathrm{Br}>\mathrm{ACP}>\mathrm{MAP}$ & $\mathrm{Br}=\mathrm{MAP}>\mathrm{ACP}$ & $\mathrm{Br}>\mathrm{ACP}>\mathrm{MAP}$ \\
\hline
\end{tabular}

*MAP: struvite, Br: Brucite, CaP: Calcium phosphate, =: same proportion, >: higher proportion. 


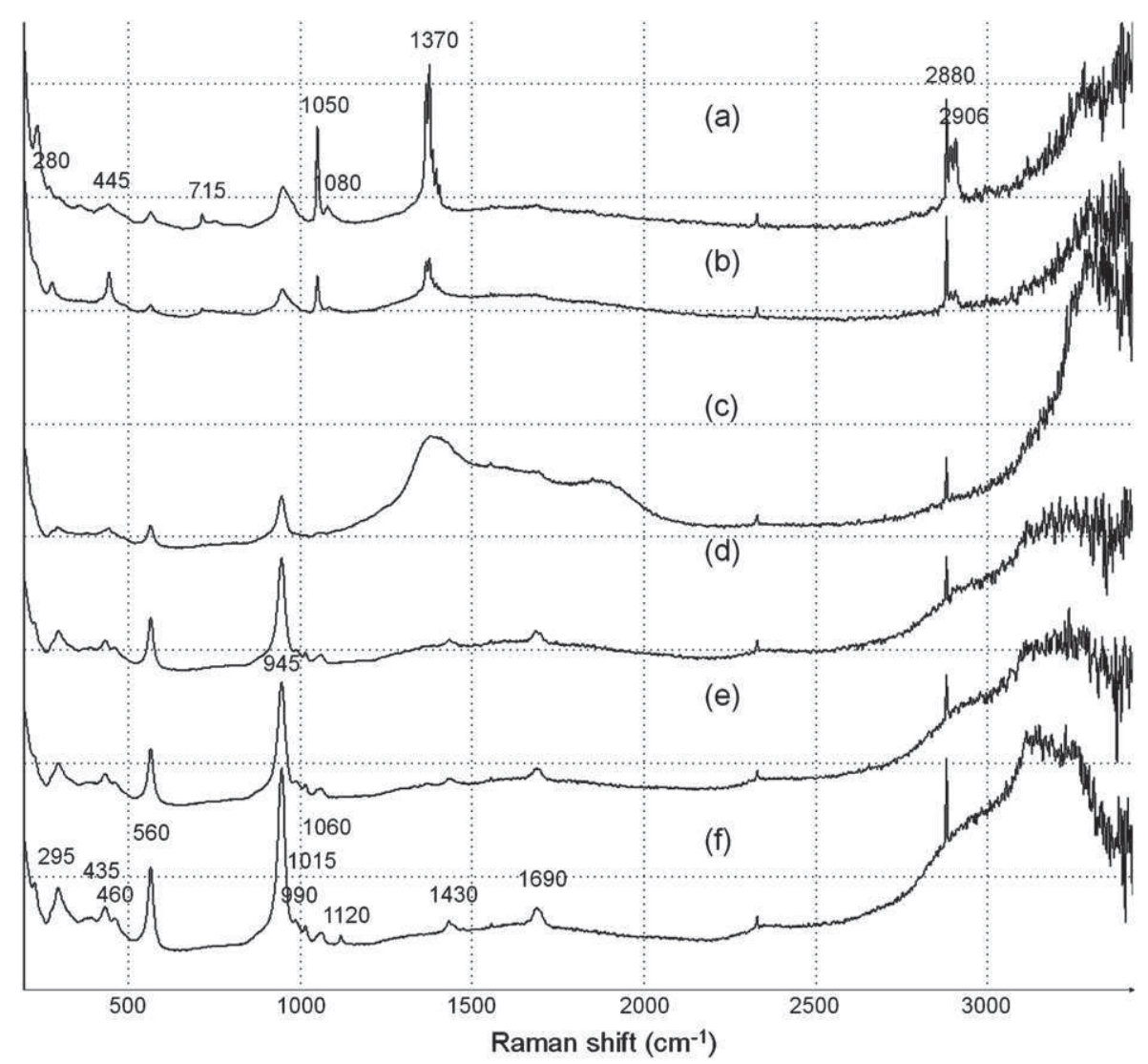

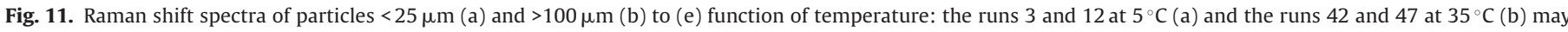

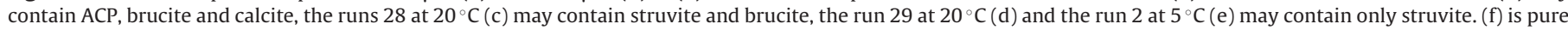
struvite from Carlo Erba (99\%)Optimization of process parameters for maximizing struvite precipitation.

Table 12

Process parameters levels for optimal desirability.

\begin{tabular}{lll}
\hline Process parameters & Levels & Levels at $15^{\circ} \mathrm{C}$ and $60 \mathrm{rpm}$ \\
\hline A:Stirring rate & $80 \mathrm{rpm}$ & $60 \mathrm{rpm}$ \\
B:Temperature & $5{ }^{\circ} \mathrm{C}$ & $15.0^{\circ} \mathrm{C}$ \\
$\mathrm{C}: \mathrm{N}: P$ molar ratio & 3 & 3 \\
$\mathrm{D}:$ initial $\mathrm{Mg}^{2+}: \mathrm{Ca}^{2+}$ molar ratio & 0.6 & 1.7 \\
$\mathrm{E}: \mathrm{Mg}^{2+}$ as MgO & $520 \mathrm{mg} \mathrm{L}^{-1}$ & $500 \mathrm{mg} \mathrm{L}^{-1}$ \\
\hline
\end{tabular}

of $-\mathrm{PO}_{4}$ ) and another at $1370 \mathrm{~cm}^{-1}$. Spectra (a) and (b) showed the presence of the characteristic peaks of phosphate, carbonate and brucite. Calcium carbonate, brucite and calcium phosphate could have precipitated in these fractions. The precipitation of $\mathrm{CaCO}_{3}$ has been already observed in struvite precipitation processes [15,52].

The optimization aimed to minimize $\left[\mathrm{PO}_{4}{ }^{3-}-\mathrm{P}\right]_{\mathrm{e}}$ and ammonia volatilization, and maximize the production of big particles of struvite. The optimum levels of parameters are given in Table 12.
A low temperature is difficult to apply in an on-farm processing plant. The process plant could stay in a closed room but temperature variations cannot be avoided. Therefore, the optimal response for the design experiment was estimated at $15^{\circ} \mathrm{C}$, the annual average temperature in Brittany (Table 12 and Table 13). Stirring rate was lowered at $60 \mathrm{rpm}$, compared to the optimal $80 \mathrm{rpm}$, due to facility restrictions.

The multiple response optimization problems were solved by combining the responses into a single index: the desirability function.

[Mg-MgO] was the leading variable that influenced the precipitation of struvite (Fig. 12). When [Mg-MgO] was low, small variations of temperature, stirring rate or initial $\mathrm{Mg}$ :Ca did not affect the desirability which stayed in a range of 0.8-1. However, variations of the $\mathrm{N}: \mathrm{P}$ molar ratio affected the desirability which decreased to 0.6 for a N:P molar ratio of 1 .

In literature, the optimal $\mathrm{pH}$ for the struvite precipitation is in a range 8 to $10[22,24,53]$. We showed that after $24 \mathrm{~h}$, in "swine wastewater conditions", the optimal pH was near 7. The Fig. 3

Table 13

Predicted and experimental responses for optimal desirability.

\begin{tabular}{|c|c|c|c|c|c|}
\hline Responses & Weight & Impact & $\begin{array}{l}\text { Optimal predicted } \\
\text { response }\end{array}$ & $\begin{array}{l}\text { Predicted response at } \\
15^{\circ} \mathrm{C} \text { and } 60 \mathrm{rpm}\end{array}$ & $\begin{array}{l}\text { Experimental response } \\
\text { at } 15^{\circ} \mathrm{C} \text { and } 60 \mathrm{rpm}\end{array}$ \\
\hline Desirability & & 3 & 0.90 & 0.86 & \\
\hline$\left[\mathrm{PO}_{4}-\mathrm{P}\right]_{\mathrm{e}}$ & 1 & 3 & $80 \mathrm{mg} \mathrm{L}^{-1}$ & $60 \mathrm{mg} \mathrm{L}^{-1}$ & $43 \pm 12 \mathrm{mg} \mathrm{L}^{-1}$ \\
\hline Particles $>100 \mu \mathrm{m}$ & 1 & 3 & $3.6 \mathrm{~g} \mathrm{~L}^{-1}$ & $3.4 \mathrm{~g} \mathrm{~L}^{-1}$ & $3.5 \pm 0.3 \mathrm{~g} \mathrm{~L}^{-1}$ \\
\hline$\%$ particles $>100 \mu \mathrm{m}$ & 1 & 3 & $67 \%$ & $60 \%$ & $87 \pm 1 \%$ \\
\hline$\% \mathrm{PO}_{4}-\mathrm{P}$ as struvite & 1 & 3 & $100 \%$ & $96 \%$ & $97 \pm 3 \%$ \\
\hline$\%$ ammonia volatilization & 1 & 3 & $2 \%$ & $8 \%$ & $1 \pm 1 \%$ \\
\hline
\end{tabular}




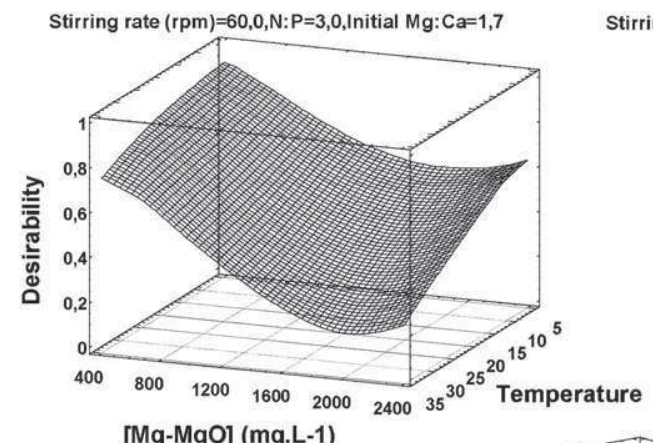

Stirring rate $(\mathrm{rpm})=60,0$, Temperature $\left({ }^{\circ} \mathrm{C}\right)=15,0$, Initial $\mathrm{Mg}: \mathrm{Ca}=1,7$

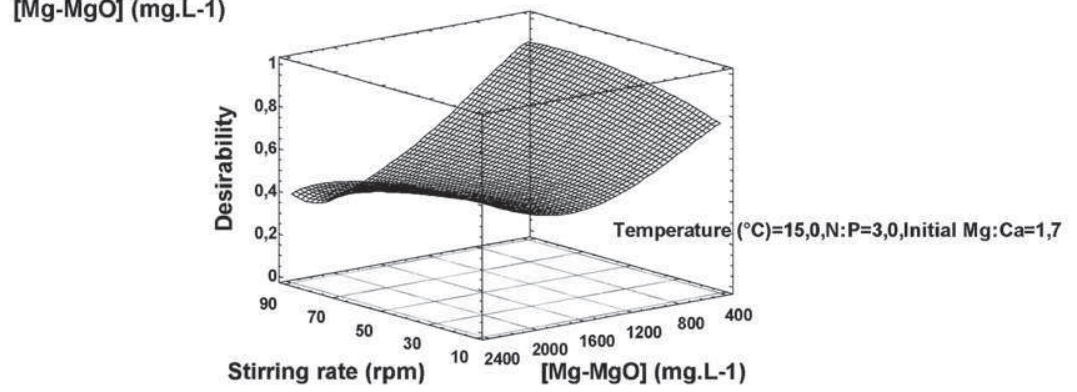

Fig. 12. $[\mathrm{Mg}-\mathrm{MgO}]$ is the leading variable that influences the statistical responses of the design of experiments.

shows that this $\mathrm{pH}$ value corresponded to about $500 \mathrm{mg} \mathrm{L}^{-1}$ of $[\mathrm{Mg}-$ $\mathrm{MgO}$. This is coherent with a study of Battistoni et al. which said that the presence of calcium speeds up the struvite precipitation at lower $\mathrm{pH}$ values [54].

\subsection{Precipitation with the optimized levels for variables}

The precipitation of struvite was performed again with the best conditions. The experiments were triplicated. One more experiment was performed to monitor the ammonia volatilization. The N:P molar ratio was 3.2 and the $\mathrm{Mg}$ :Ca molar ratio was 2.3. Maximal $\mathrm{pH}$ was then 6.7. The experimental responses are presented in Table 13.

After $24 \mathrm{~h}$, all particles were in the fractions $>25 \mu \mathrm{m}$. The $\mathrm{MgO}$ entirely dissolved and the particles of calcium phosphate were in the fractions $>25 \mu \mathrm{m}$.

The proportion of struvite versus calcium phosphate in dried solids was $76 \% \pm 9 \%$ in the fraction $25-100 \mu \mathrm{m}$ and increased to

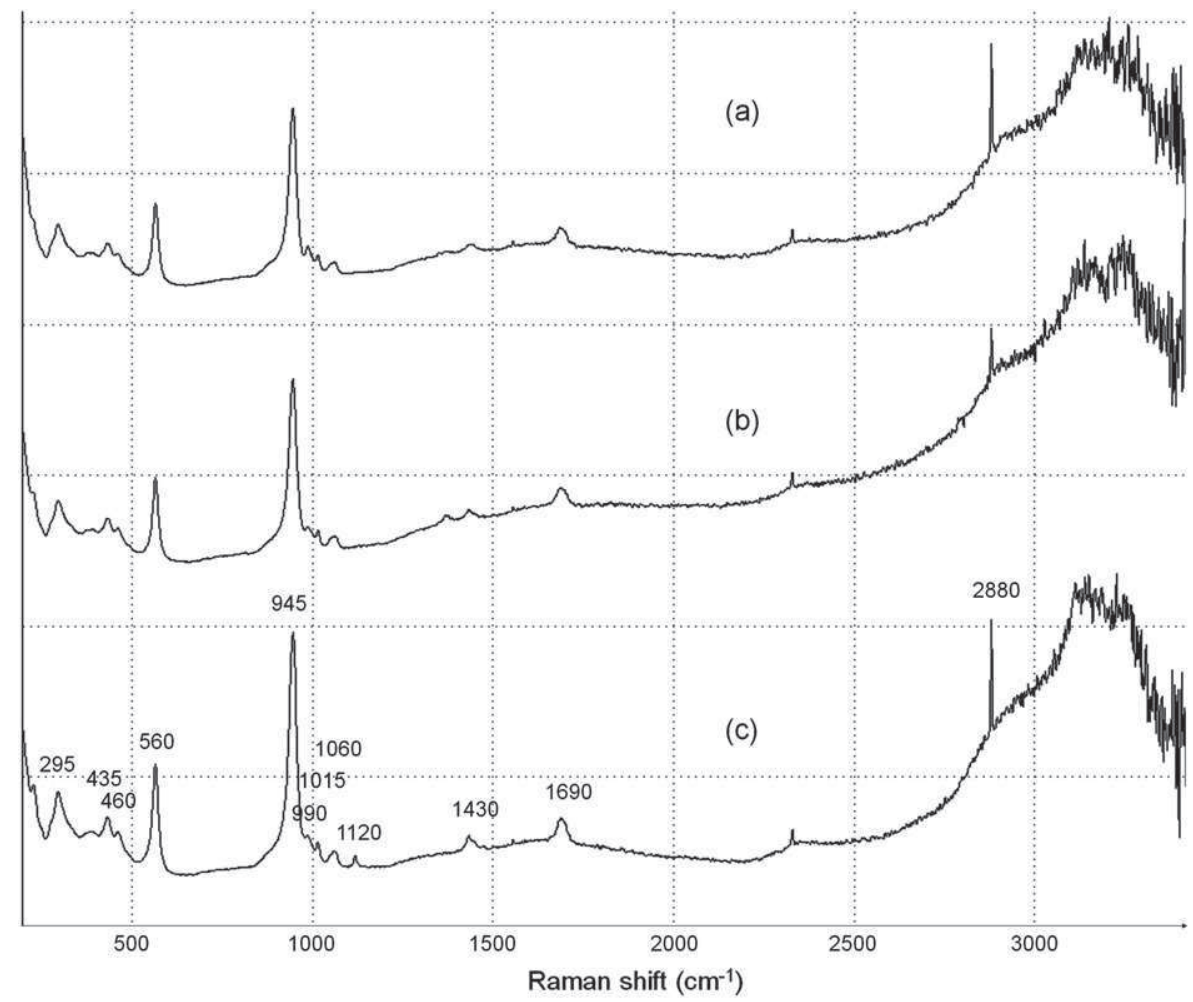

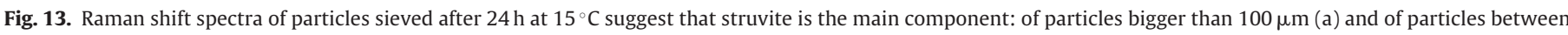
25 and $100 \mu \mathrm{m}$ (b). (c) is pure struvite from Carlo Erba (99\%). 
$86 \% \pm 2 \%$ in the fraction $>100 \mu \mathrm{m}$. These results confirm the results of the statistical model.

The optimal levels for variables might have not only improved the size of struvite crystals but also increased the size of calcium phosphate particles. In part 3.3, a Ca:P molar ratio near 1 indicated the presence of $A C P$. In the 48 runs, this ratio was observed in the fractions $<25 \mu \mathrm{m}$. In the optimization run, this ratio was observed in the fraction $25-100 \mu \mathrm{m}$. ACP could have precipitated in this solid fraction. However Raman analysis (spectrum (b) in Fig. 13) did not show the characteristic peaks of calcium phosphate: the proportion of struvite in dried solids was much larger than calcium phosphate.

In the optimization run, Ca:P molar ratio was $0.57 \pm 0.04$ in the fraction $>100 \mu \mathrm{m}$ which was similar to results obtained in experimental design.

\section{Conclusions}

The optimization of the precipitation of struvite in a stirred beaker made it possible to recycle more than $90 \%$ of phosphorus in large crystals of struvite despite of the presence of large amounts of calcium and using a cheap reactant such as $\mathrm{MgO}$.

The optimal conditions for the removal of phosphorus as large crystals of struvite in synthetic swine wastewater were: low $\mathrm{Mg}: \mathrm{Ca}$ molar ratio (2.25:1), the leading parameter, high $\mathrm{N}: \mathrm{P}$ molar ratio (3:1), moderate stirring rate (between 45 and $90 \mathrm{rpm}$ ) and low temperature (below $20^{\circ} \mathrm{C}$ ).

High N:P molar ratio improved the precipitation of struvite instead of calcium phosphate. Low concentrations of MgO induced a low supersaturation which improved the size of the struvite crystals; it also minimized ammonia volatilization.

Raman analysis and solid dissolution in acid made the identification of the composition of the product possible. These analyses revealed that: ACP co-precipitated with struvite, carbonates were incorporated into solid fractions and brucite precipitated in almost all of the runs. The Raman analyses were coherent with the SI values calculated by Phreeqc.

The runs lasted for $24 \mathrm{~h}$ in order to reach equilibrium. The size and the composition of the precipitated solids could evolve before reaching the equilibrium. Further analysis is needed to understand evolution of the solid phases over 24-hours.

\section{Acknowledgements}

This work is supported by the "Conseil Régional de la Bretagne", by the French Research National Agency (ANR) and by specific university research (MSMT No 21/2012).

\section{References}

[1] A. Smit, P. Bindraban, J. Schröder, J. Conjin, H. Van der Meer, Phosphorus in Agriculture: Global Resources, Trends and Developments, Report to the Steering Committee Technology Assessment of the Ministry of Agriculture, The Neetherlands, Wageningen, 2009.

[2] R. Gonzalez Ponce, Evaluation of struvite as a fertilizer: a comparison with traditional P sources, Agrochimica 51 (2007) 301-308.

[3] M.-L. Daumer, F. Béline, M. Spérandio, C. Morel, Relevance of a perchloric acid extraction scheme to determine mineral and organic phosphorus in swine slurry, Bioresour. Technol. 99 (2008) 1319-1324.

[4] M.-L. Daumer, S. Picard, P. Saint-Cast, P. Dabert, Technical and economical assessment of formic acid to recycle phosphorus from pig slurry by a combined acidification-precipitation process, J. Hazard. Mater. 180 (2010) 361-365.

[5] K.S. Le Corre, Understanding Struvite Crystallisation and Recovery, Cranfiel University, School of Applied Science, Department of Sustainable System, Center for Water Science, 2006.

[6] N. Hutnik, K. Piotrowski, B. Wierzbowska, A. Matynia, Continuous reaction crystallization of struvite from phosphate $(\mathrm{V})$ solutions containing calcium ions, Cryst. Res. Technol. 46 (2011) 443-449.

[7] J. Mullin, Crystallization, fourth ed., Butterworth Heinemann, 2001.

[8] A. Mersmann, Crystallization Technology Handbook, second, CRC, 2001.

[9] M.I.H. Bhuiyan, D.S. Mavinic, R.D. Beckie, Nucleation and growth kinetics of struvite in a fluidized bed reactor, J. Cryst. Growth 310 (2008) 1187-1194.
[10] K. Byrappa, International School on Crystal Growth of Technologically Important Electronic Materials, Allied Publishers, 2003.

[11] J. Koralewska, K. Piotrowski, B. Wierzbowska, A. Matynia, Kinetics of reaction-crystallization of struvite in the continuous draft tube magma type crystallizers-influence of different internal hydrodynamics, Chin. J. Chem. Eng. 17 (2009) 330-339.

[12] F. Abbona, M. Franchini-Angela, Crystallization of calcium and magnesium phosphates from solutions of low concentration, J. Cryst. Growth 104 (1990) 661-671.

[13] F. Abbona, H.E.L. Madsen, R. Boistelle, The initial phases of calcium and magnesium phosphates precipitated from solutions of high to medium concentrations, J. Cryst. Growth 74 (1986) 581-590.

[14] F. Abbona, H.E. Lundager Madsen, R. Boistelle, The final phases of calcium and magnesium phosphates precipitated from solutions of high to medium concentration, J. Cryst. Growth 89 (1988) 592-602.

[15] I. Kabdaşli, O. Tünay, M.Ş. Çetin, T. Ölmez, Assessment of magnesium ammonium phosphate precipitation for the treatment of leather tanning industry wastewaters, Water Sci. Technol. 46 (2002).

[16] O. Tünay, I. Kabdasli, D. Orhon, S. Kolçak, Ammonia removal by magnesium ammonium phosphate precipitation in industrial wastewaters, Water Sci. Technol. 36 (1997) 225-228.

[17] M.L. Daumer, F. Béline, S.A. Parsons, Chemical recycling of phosphorus from piggery wastewater, in: Intl Water Assn, Vancouver, 2009, pp. 339-350.

[18] I. Lopez-Valero, C. Gomez-Lorente, R. Boistelle, Effects of sodium and ammonium ions on occurrence, evolution and crystallinity of calcium phosphates, J. Cryst. Growth 121 (1992) 297-304.

[19] D. Crutchik, J.M. Garrido, Struvite crystallization versus amorphous magnesium and calcium phosphate precipitation during the treatment of a saline industrial wastewater, Water Sci. Technol. 64 (2011) 2460.

[20] K.S. Le Corre, E. Valsami-Jones, P. Hobbs, S.A. Parsons, Kinetics of struvite precipitation: effect of the magnesium dose on induction times and precipitation rates, Environ. Technol. 28 (2007) 1317-1324

[21] Z.-L. Ye, S.-H. Chen, S.-M. Wang, L.-F. Lin, Y.-J. Yan, Z.-J. Zhang, et al., Phosphorus recovery from synthetic swine wastewater by chemical precipitation using response surface methodology, J. Hazard. Mater. 176 (2010) 1083-1088.

[22] J.D. Doyle, R. Philp, J. Churchley, S.A. Parsons, Analysis of struvite precipitation in real and synthetic liquors, Process Saf. Environ. Prot. 78 (2000) 480-488.

[23] A. Uysal, Y.D. Yilmazel, G.N. Demirer, The determination of fertilizer quality of the formed struvite from effluent of a sewage sludge anaerobic digester, J. Hazard. Mater. 181 (2010) 248-254.

[24] D. Kim, H.-D. Ryu, M.-S. Kim, J. Kim, S.-I. Lee, Enhancing struvite precipitation potential for ammonia nitrogen removal in municipal landfill leachate, J. Hazard. Mater. 146 (2007) 81-85.

[25] E.V. Münch, K. Barr, Controlled struvite crystallisation for removing phosphorus from anaerobic digester sidestreams, Water Res. 35 (2001) 151-159.

[26] J. Goupy, Les plans d'expérience pour surface de réponse, Dunod, 1999.

[27] M. Hanhoun, L. Montastruc, C. Azzaro-Pantel, B. Biscans, M. Frèche, L. Pibouleau, Temperature impact assessment on struvite solubility product: a thermodynamic modeling approach, Chem. Eng. J. 167 (2011) 50-58.

[28] A. Mañas, M. Pocquet, B. Biscans, M. Sperandio, Parameters influencing calcium phosphate precipitation in granular sludge sequencing batch reactor, Chem. Eng. Sci. 77 (2012) 165-175.

[29] M. Altmaier, V. Metz, V. Neck, R. Müller, T. Fanghänel, Solid-liquid equilibria of $\mathrm{Mg}(\mathrm{OH}) 2(\mathrm{cr})$ and $\mathrm{Mg} 2(\mathrm{OH}) 3 \mathrm{Cl} 4 \mathrm{H} 2 \mathrm{O}(\mathrm{cr})$ in the system Mg-Na-H-OH-Cl-H2O at $25^{\circ} \mathrm{C}$, Geochim. Cosmochim. Acta 67 (2003) 3595-3601.

[30] J.C. Deelman, Low-Temperature Formation of Dolomite and Magnesite, Compact Disc Publications, 2003.

[31] X.L. Deng, Y.M. Luo, M.M. Xu, X.Y. Hu, Influence of solvent polarity on synthesis of beta - tricalcium phosphate, Key Eng. Mater. 330-332 (2007) 143-146.

[32] F. Abbona, A. Baronnet, A XRD and TEM study on the transformation of amorphous calcium phosphate in the presence of magnesium, J. Cryst. Growth 165 (1996) 98-105.

[33] P. Battistoni, A. De Angelis, P. Pavan, M. Prisciandaro, F. Cecchi, Phosphorus removal from a real anaerobic supernatant by struvite crystallization, Water Res. 35 (2001) 2167-2178

[34] M. Quintana, E. Sanchez, M.F. Colmenarejo, J. Barrera, G. Garcia, R. Borja, Kinetics of phosphorus removal and struvite formation by the utilization of by-product of magnesium oxide production, Chem. Eng. J. 111 (2005) 45-52.

[35] A.A. Szögi, M.B. Vanotti, Removal of phosphorus from livestock effluents, J. Environ. Qual. 38 (2009) 576.

[36] M.B. Vanotti, A.A. Szogi, P. Hunt, Extraction of soluble phosphorus from swine wastewater, Trans. ASAE 46 (2003) 1665-1674

[37] F. Montes, C.A. Rotz, H. Chaoui, Process modeling of ammonia volatilization from ammonium solution and manure surfaces: a review with recommended models, Trans. ASABE 52 (2009) 1707-1719.

[38] M. Kazanci, P. Fratzl, K. Klaushofer, E.P. Paschalis, Complementary information on in vitro conversion of amorphous (precursor) calcium phosphate to hydroxyapatite from raman microspectroscopy and wide-angle X-ray scattering, Calcif. Tissue Int. 79 (2006) 354-359.

[39] M. Ronteltap, M. Maurer, R. Hausherr, W. Gujer, Struvite precipitation from urine - influencing factors on particle size, Water Res. 44 (2010) 2038-2046.

[40] M. Rivadeneyra, R. Delgado, J. Párraga, A. Ramos-Cormenzana, G. Delgado, Precipitation of minerals by 22 species of moderately halophilic bacteria in artificial marine salts media: Influence of salt concentration, Folia Microbiol. 51 (2006) 445-453. 
[41] M. Sánchez-Román, C.S. Romanek, D.C. Fernández-Remolar, A. Sánchez-Navas, J.A. McKenzie, R.A. Pibernat, et al., Aerobic biomineralization of Mg-rich carbonates: Implications for natural environments, Chem. Geol. 281 (2011) 143-150.

[42] L. Pastor, D. Mangin, J. Ferrer, A. Seco, Struvite formation from the supernatants of an anaerobic digestion pilot plant, Bioresour. Technol. 101 (2010) 118-125.

[43] N. Martí, L. Pastor, A. Bouzas, J. Ferrer, A. Seco, Phosphorus recovery by struvite crystallization in WWTPs: Influence of the sludge treatment line operation, Water Res. 44 (2010) 2371-2379.

[44] J.A. Wojtowicz, Calcium carbonate precipitation potential, J. Swimming Pool Spa Ind. 2 (2001) 23-29.

[45] S.V. Dorozhkin, Amorphous calcium (ortho)phosphates, Acta Biomater. 6 (2010) 4457-4475.

[46] R.L. Frost, M.L. Weier, W.N. Martens, D.A. Henry, S.J. Mills, Raman spectroscopy of newberyite, hannayite and struvite, Spectrochim. Acta A 62 (2005) 181-188.

[47] V. Stefov, B. Šoptrajanov, I. Kuzmanovski, H.D. Lutz, B. Engelen, Infrared and Raman spectra of magnesium ammonium phosphate hexahydrate (struvite) and its isomorphous analogues. III. Spectra of protiated and partially deuterated magnesium ammonium phosphate hexahydrate, J. Mol. Struct. 752 (2005) 60-67.

[48] V. Stefov, B. Šoptrajanov, F. Spirovski, I. Kuzmanovski, H. Lutz, B. Engelen, Infrared and Raman spectra of magnesium ammonium phosphate hexahydrate (struvite) and its isomorphous analogues. I. Spectra of protiated and partially deuterated magnesium potassium phosphate hexahydrate, J. Mol. Struct. 689 (2004) 1-10.

[49] F. Pascale, S. Tosoni, C. Zicovich-Wilson, P. Ugliengo, R. Orlando, R. Dovesi, Vibrational spectrum of brucite, $\mathrm{Mg}(\mathrm{OH})_{2}$ : a periodic ab initio quantum mechanical calculation including $\mathrm{OH}$ anharmonicity, Chem. Phys. Lett. 396 (2004) 308-315.

[50] H.G.M. Edwards, S.E.J. Villar, J. Jehlicka, T. Munshi, FT-Raman spectroscopic study of calcium-rich and magnesium-rich carbonate minerals, Spectrochim. Acta, Part A 61 (2005) 2273-2280.

[51] C. Paluszkiewicz, M. Gałka, W. Kwiatek, A. Parczewski, S. Walas, Renal stone studies using vibrational spectroscopy and trace element analysis, Biospectroscopy 3 (1997) 403-407.

[52] P. Battistoni, R. Boccadoro, F. Fatone, P. Pavan, Auto-nucleation and crystal growth of struvite in a demonstrative fluidized bed reactor (FBR), Environ. Technol. 26 (2005) 975-982.

[53] H. Huang, C. Xu, W. Zhang, Removal of nutrients from piggery wastewater using struvite precipitation and pyrogenation technology, Bioresour. Technol. 102 (2011) 2523-2528.

[54] P. Battistoni, P. Pavan, M. Prisciandaro, F. Cecchi, Struvite crystallization: a feasible and reliable way to fix phosphorus in anaerobic supernatants, Water Res. 34 (2000) 3033-3041. 